\title{
UNIFORM INTERNATIONAL TAX COLLECTION AND DISTRIBUTION FOR GLOBAL DEVELOPMENT, A UTOPIAN BEPS ALTERNATIVE
}

\author{
Henry Ordower*
}

\begin{abstract}
Under the guise of compelling multinational enterprises (MNEs) to pay their fair share of income taxes, the OECD and other multinational agencies have introduced proposals to prevent MNEs from eroding the income tax base of developed economies by continuing to shift income artificially to low or zero tax jurisdictions. Some of the proposals have garnered substantial multinational support, including recent support from the new U.S. presidential administration for a global minimum tax. This Article reviews many of those international proposals. The proposals tend to concentrate the incremental tax revenue from the prevention of base erosion into the treasuries of the developed economies although the minimum tax proposal known as GloBE encourages low tax countries to adopt the minimum rate. The likelihood that zero tax countries will transition successfully to imposing the minimum tax seems uncertain.

Developed economies lack a compelling moral claim to incremental revenue so this Article argues that collecting a fair tax from MNEs and other taxpayers should be a goal that is independent of claims on that revenue. This Article maintains that to prevent tax base erosion, the income tax base and administration must be uniform across national borders and the Article recommends applying uniform rules administered by an international taxing agency. The Article explores the convergence of tax rules under such an international taxing agency.

Distribution of tax revenue by the international agency should follow contextualized need. In addressing the conundrum of absolute poverty in the undeveloped and developing world vis á vis relative poverty in the developed world, the Article proposes that the taxing agency should distribute all incremental revenue from the uniform tax where the need is greatest to ameliorate absolute poverty and improve living standards without regard to income source. The location of income production, destination of the produced

\footnotetext{
* Saint Louis University School of Law. A.B. Washington University; M.A., J.D. The University of Chicago. I am grateful to Hannah Meehan (now, Hannah Hope), a $3^{\text {rd }}$ year law student at Saint Louis University School of Law, for outstanding research and facilitating the progress of this paper. Thanks also to David Kullman, a librarian and library liaison, and Joel Ocampo, a recent graduate from Saint Louis University School of Law, for additional research assistance, and my spouse Ilene Ordower for her support and proofreading. Special thanks to Allison Christians for her time in wading through an earlier draft of this paper to provide indispensable suggestions and to Alexis Brassey, my co-author on a related article, for his insights about relative and absolute poverty. Thanks also to the attendees at the presentation of an earlier draft of this paper at the Law and Society 2020 virtual conference and to Victor Fleisher, Victor Thuronyi, and Reuven Avi-Yonah for comments at the 2021 Critical Tax Conference. Finally, many thanks to the editors and staff of the Columbia Journal of Tax Law for their critical reading and commentary preparing this Article for publication.
} 
goods and services generating the income, and residence of the income producers should not determine the tax revenue distribution. Rather, the use of contextualized need for distribution determination will enable developed economies to receive sufficient revenue to maintain their existing infrastructures and governmental services. Developed economies should forego new revenue, for which they have not budgeted, in favor of improving worldwide living conditions for all. The proposals for uniform, worldwide taxation and revenue sharing based on contextualized need are admittedly aspirational and utopian but designed to encourage debate on sharing of resources in our increasingly globalized world.

I. INTRODUCTION 127

II. CONTEXTUALIZING THE GLOBAL TAXING PROBLEM …............................ 129

III. REGIONALISM AND TAXING JURISDICTIONS …......................................... 137

IV. INTERNATIONAL TAX COMPETITION AND REALLOCATING THE TAX BASE

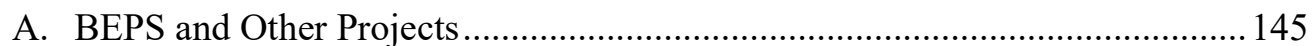

B. GloBE - Minimum Tax and Base Erosion .................................................... 148

C. Tax Competition, Avoidance, and Evasion ................................................... 152

D. Tax Base Allocation and Apportionment ...................................................... 154

V. THE RELATIVE AND ABSOLUTE POVERTY CONUNDRUM ...................... 157

VI. AN INTERNATIONAL TAXING AGENCY FOR AN ECONOMICALLY GLOBALIZED WORLD: ABANDONING MYTHICAL TAX SOVEREIGNTY

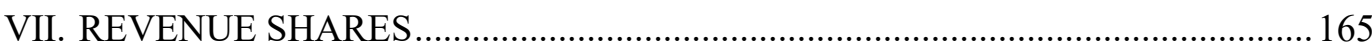

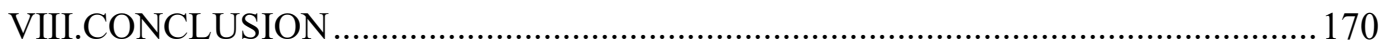

\section{INTRODUCTION}

International tax reform projects, including the $\mathrm{OECD}^{1}$ Base Erosion and Profit Shifting (BEPS) iterations, seek to collect additional tax from multi-national enterprises (MNEs) under the rubric of fairer taxation. The reform projects propose various methods of reallocating income that taxpayers have sourced to low and zero tax jurisdictions to affluent developed economies for those economies to tax under their own tax regimes. Such reallocations would concentrate the bulk of incremental tax revenue into the treasuries of affluent developed economies.

This Article maintains that the need to prevent taxpayers from avoiding payment of a fair tax amount should not result in additional tax revenue primarily for the economically developed economies. Arguments that the right to tax belongs to the developed economies are largely political, not moral. The arguments lack persuasive force in a world of unequal distribution of wealth and resources with which to generate wealth. Fair tax collection should yield incremental revenue to eliminate poverty and improve living conditions for all people worldwide. Current international tax reform projects fail to address world poverty adequately.

The Article proposes as an alternative to other international projects the creation of an international taxing agency to substitute for national taxing agencies worldwide. The

\footnotetext{
${ }^{1}$ The Organisation for Economic Co-operation and Development (OECD) is a member organization with 37 developed countries as members. Member Countries, OECD, https://www.oecd .org/about/document/list-oecd-member-countries.htm [https://perma.cc/NHD4-A3BM] (last visited May 21, 2020).
} 
international taxing agency would target elimination of world poverty. The new agency would have full authority to collect income taxes from entities and individuals under uniform international, rather than disparate national, taxing rules and procedures and to distribute the revenue worldwide. This international taxing agency would render obsolete most or all international tax reform projects and eliminate the need for most or all tax treaties and tax information exchange agreements.

Uniform rules and rates applicable to all income worldwide without regard to the source, residence, or market from or in which the income is produced will facilitate the collection of an aggregate worldwide tax greater in amount than that currently collected by all the fragmented, national tax collection. Unlike existing national tax systems, such a tax, owing to its uniformity, would not favor some taxpayers over others.

Since the global tax will increase tax revenue collection materially, distribution initially might follow a two-step formula. The first step would hold each country harmless from tax revenue loss so that following transition to the global tax, each country receives a share of tax revenue equal to its revenue from income tax in the preceding year, or an average of several years' collections, possibly adjusted for inflation, and enable each country to maintain its infra- and superstructure. The second step would follow a needsbased assessment under which the nutrition, housing, education, healthcare and infrastructure needs of less developed countries would be evaluated and a plan developed to ameliorate deficits in all categories worldwide. The agency would distribute incremental tax revenue pursuant to that plan. The second step would devote incremental revenue to the gradual elimination of those deficits - perhaps addressing life-threatening deficits first, followed by improvement of living standards everywhere. Tax revenue thus transferred to non-affluent, developing economies initially would be small relative to the amount of revenue distributed under the first step to enable developed economies to maintain their existing infra- and superstructures, but poverty amelioration costs would be moderated as a function of relative local cost of goods and labor. Nevertheless, the amount of tax revenue devoted to international poverty relief would be far greater than the minimal amounts developed economies currently contribute to world poverty eradication.

The Article proceeds as follows. Part II contextualizes the problem of base erosion against revenue collection and distribution and provides an overview of the international taxing issues that this Article addresses. Part III considers a U.S. regional context as a microcosm in which multiple and often overlapping taxing jurisdictions compete for revenue and investment. Some seek to capture additional revenue by annexing high tax yield property, and others with extra tax and, at times, predatory revenue collection. Many exchange tax concessions for development and highlight the problems of tax competition and proliferating taxing jurisdictions even in the face of centralized tax collection. This part presents a relatively complex proxy for the revenue-raising problems confronting multiple taxing jurisdictions that fail to coordinate their efforts despite the umbrella of a larger governmental unit to which they belong. Part IV reviews a variety of proposals and related commentary-BEPS, GloBE, CCCTB-highlighting the difficulty of harmonization in the face of tax competition and relentless industry pressure for taxfavored treatment. Part V introduces the factor of relative and absolute poverty and regional development needs that contribute to the proliferation of taxing concessions in exchange for international investment, even where the benefit from the inbound investment is compromised by the loss of potential tax revenue and the corrupt reallocation of the potential revenue into private hands. Part VI envisions relinquishment of national tax sovereignty in favor of an international taxing agency with the power to assess and collect 
tax at a uniform rate or rates under uniform international taxing rules without regard to source, residence, or sales. It would base the authority to tax on multiple independent factors so that virtually all income is included and taxed in the worldwide base the international agency administers. Part VII recommends negotiation of revenue shares to dissuade regions from tax competition. It also suggests constructing a framework for formulaic revenue distribution based on relative economic need, including the maintenance of existing infrastructures. Part VIII concludes and acknowledges that the Article's proposals indeed are utopian and remain distant from capturing immediate, worldwide acceptance of an international taxing agency. Nevertheless, the Article's proposals are intended to motivate further international conversation of the critical need for tax base convergence in support of uniform taxation - even if only a minimum tax — and provide a model for global distribution of incremental revenue from uniform taxation to ameliorate global economic needs rather than further enriching the world's developed economies.

\section{CONTEXTUALIZING THE GLOBAL TAXING PROBLEM}

As corporations grew and increased their cross-border reach through the twentieth century, they adapted to doing business in multiple jurisdictions under a single enterprise umbrella. Such MNEs centralized their management, notwithstanding national borders. Many were sufficiently flexible to disperse management functions by operation or geography to maximize profitability although all functions remained answerable to central management. ${ }^{2}$ The MNE's international business models enabled them to situate operations where costs were lowest or regional features most favorable for specific business functions. MNEs flexed their economic muscle to encourage robust, interjurisdictional, and international competition for their investment. From time to time, the competition became destructive to the host jurisdiction because the fervor to meet such competition sometimes caused the host jurisdiction to relinquish resources exceeding the benefits received from the investment. Taxation became a mainstay of that competition. MNEs demanded and received tax concessions from a jurisdiction before making or increasing their investments in the jurisdiction.

Governments have not been nearly so nimble in adjusting their tax systems to capture revenue from the MNEs. Neither have governments adopted a unified or harmonized approach to taxation, even though compromising their taxing sovereignty with harmonized tax rules and procedures might yield better tax revenue production. Instead, tax competition has trended both on project-specific items as a substitute for direct subsidies and, on the broader scale, to encourage relocation of some or all of the MNEs' activities from higher tax jurisdictions to jurisdictions that would offer substantially lower or even zero tax rates in exchange for investment. And it is not only MNEs to which nations have offered tax-based investment incentives. Jurisdictions commonly offer

${ }^{2}$ OECD, Multinational Enterprises in The Global Economy-Heavily Debated But HaRdly MEASURED (May 2018), https://www.oecd.org/industry/ind/MNEs-in-the-globaleconomy-policy-note.pdf [https://perma.cc/UC28-ZQCG] (activities undertaken by foreign affiliated MNEs grew by $\$ 13$ trillion from 2000 to 2014); Mark J. Perry, Many Large US Firms Sell, Hire, and Invest More Overseas than in US and Have to Think Globally to Survive, AM. EnTER. Inst. (June 22, 2020), https://www.aei.org/carpe-diem/many-large-us-firms-sell-hire-and-invest-more-overseasthan-in-the-us-and-have-to-think-globally-to-survive/ [https://perma.cc/Y4BB-TLRF] (U.S. Based companies in the world's top 100 multinational companies have foreign assets accounting for $23.8 \%$ to $82.4 \%$ of their total assets, and foreign employment accounting for $23.8 \%$ to $87.9 \%$ of their total employment). 
immigrant or resident visas to investors ${ }^{3}$ and have begun to include temporary tax holidays as additional immigration incentives. ${ }^{4}$

Higher tax jurisdictions have not conceded their right to tax the MNEs, but they have found resourceful tax planners and competitive taxing jurisdictions to be formidable foes. Efforts to overcome tax competition and planning have enjoyed limited success. Regarding the income tax, combatting tax planning and tax competition (with some exceptions) $)^{5}$ has been largely national. Some tools that legislatures and tax administrators deploy to staunch loss of revenue from competition, such as general anti-avoidance rules, have been enacted into law in similar forms in numerous jurisdictions, ${ }^{6}$ reflecting legislative willingness to borrow tax concepts from other jurisdictions and adapt them to address challenging problems. ${ }^{7}$

The OECD has assumed the lead in the international tax arena and, for the past several decades, has supplemented tax treaties ${ }^{8}$ with other multinational tools for tax collectors to share tax information in the form of similar, but more limited, international agreements. ${ }^{9}$ As in the case of treaties, ${ }^{10}$ exchange of information through tax agency cooperation may facilitate tax offender prosecution. More recently, the OECD introduced and developed several projects designed to identify and capture individuals' and MNEs' income that they have assigned artificially to low tax jurisdictions. ${ }^{11}$ In one project, the OECD sought to coerce low tax jurisdictions to step back from encouraging taxpayers to move investment from high tax jurisdictions to low tax ones and to cooperate in exchanging tax information so that jurisdictions could tax their resident taxpayers on income received

${ }^{3}$ See Leila Adim, Between Benefit and Abuse: Immigrant Investment Programs, 62 ST. LouIs U. L.J. 121 (2017); Allison Christians, Buying In: Residence and Citizenship by Investment, 62 ST. LouIS U. L.J. 51 (2017).

${ }^{4}$ E.g., Raul-Angelo Papotti \& Lorenzo Ferro, Italy's Attractive New Tax Regime for Wealthy Pensioners, 94 TAX NotEs INT'L 443 (Apr. 29, 2019); Marco Q. Rossi, Italy's Special Tax Regime for High-Net-Worth Individuals, Three Years In, 98 TAX NOTES INT'L 1145 (June 8, 2020).

${ }^{5}$ See discussion infra Part III.

${ }^{6}$ General Anti-avoidance Rules (GAARs) have become commonplace although effective use has been limited. See Rebecca Prebble \& John Prebble, Does the Use of General Anti-Avoidance Rules to Combat Tax Avoidance Breach Principles of the Rule of Law? A Comparative Study, 55 ST. LouIs U. L.J. 21, 25-27 (2010). The U.S. does not have a GAAR scheme but the statutory economic substance rule in section 7701(o) operates similarly to other countries' GAARs and requires that a transaction have economic substance independent of its tax benefits, although the government appears to have used that section, as well as a specific partnership anti-avoidance regulation primarily as additional arguments in litigation (although both may have had impact on settlements with taxpayers. See I.R.C. $\S 7701(0)$; Treas. Reg. $§ 1.701-2$. Similarly, controlled foreign corporation (CFC) anti-avoidance rules similar to those in section 951 have been enacted in several jurisdictions. See I.R.C. $\S 951$.

${ }^{7}$ See Anthony Infanti, The Ethics of Tax Cloning, 6 FLA. TAx Rev. 253 (2003).

${ }^{8}$ See, e.g., Convention with Respect to Taxes on Income and Capital, U.S.-Can., Sep. 26, 1980, 1469 U.N.T.S. 189 (tax treaty based on OECD model).

${ }^{9}$ Tax Information Exchange Agreements, OECD, https://www.oecd.org/ctp/exchange-oftax-information/taxinformationexchangeagreementstieas.htm [https://perma.cc/43XU-6V55] (last visited June 17, 2020) [hereinafter TIEA]; Automatic Exchange Portal, OECD, http://www.oecd.org/tax/automatic-exchange/ [https://perma.cc/BL26-7UHF] (last visited June 17, 2020) (collaboration between OECD and the Global Forum on Transparency and Exchange of Information for Tax Purposes in area of automatic exchange information with respect to Common Reporting Standard).

${ }^{10}$ See, e.g., Convention with Respect to Taxes on Income and Capital art. XXVII, U.S.Can., Sep. 26, 1980, 1469 U.N.T.S. 189).

${ }^{11}$ See infra Part III. 
in other jurisdictions where appropriate. ${ }^{12}$ The OECD developed a list of un-cooperative tax havens and gradually removed jurisdictions from the list as they agreed to respect OECD standards of transparency and exchange of information. ${ }^{13}$ It removed the last three countries, Andorra, Monaco and Liechtenstein, from the list in May 2009. ${ }^{14}$ The European Union (EU) maintains its own active list of uncooperative tax jurisdictions that currently includes eleven island jurisdictions and Oman. ${ }^{15}$

More recent projects focus on MNE revenue and seek to reallocate the revenue from the source to which the taxpayer has assigned it to a higher tax jurisdiction through sourcing rules designed to diminish the ability of taxpayers to shift profit artificially from high to low tax jurisdictions. ${ }^{16} \mathrm{~A}$ working group under the European Commission introduced a voluntary proposal for a common consolidated corporate tax basis (CCCTB) that, if adopted, would apportion the income of MNEs formulaically and predictably among the EU states in which they are operating. ${ }^{17}$ After tabling the proposal earlier, the EC renewed the proposal in 2015 as a mandatory base with a gradual introduction. ${ }^{18}$ The EU also has become more attentive to the state aid issues prohibited by the Treaty of the Functioning of the EU (TFEU) ${ }^{19}$ when its member states grant non-uniform tax concessions to enterprises to provide a welcoming tax environment for them. ${ }^{20}$

12 OeCD, Harmful tax Competition An Emerging Global Issue 16 (1998), https://www.oecd.org/tax/harmful/1904176.pdf [https://perma.cc/AF4Y-X76D] (identifying harmful tax practices and tax havens to encourage developed countries to abandon such practices and impose sanctions on tax haven jurisdictions facilitating secret investment from residents of developed economies using tax havens to avoid home country taxes) [hereinafter OECD HARMFUL TAX COMPETITION].

13 List of Unco-operative Tax Havens, OECD, https://www.oecd.org /countries/monaco/list-of-unco-operative-tax-havens.htm [https://perma.cc/NHM5-L968] (last visited June 17, 2020) [hereinafter OECD, Unco-operative Tax Havens]. But see Michael J. McIntyre, How to End the Charade of Information Exchange, 56 TAX NOTES INT'L 255 (Oct. 26, 2009) (arguing against the effectiveness of the TIEA as a basis on which to remove jurisdictions from the list of tax havens, characterizing the U.S. - Switzerland agreement as changing little of the Swiss bank secrecy-based assistance to international tax cheats, and proposing an alternative).

${ }^{14} \mathrm{OECD}$, Unco-operative Tax Havens, supra note 13.

${ }^{15}$ Council Conclusions on the Revised EU List of Non-cooperative Jurisdictions for Tax Purposes, 2020 O.J. (C 64) 8 [hereinafter EU List of Non-cooperative Jurisdictions]

16 Base Erosion And Profit Shifting (BEPS), OECD, https://www.oecd.org/tax/beps/ [https://perma.cc/TM94-6GRP] (last visited July 10, 2020); Michael P. DEVEREUX ET AL., OXFORD Ctr. Bus. TaX’n., The OECD Global Anti-Base Erosion (GloBE) Proposal 1-2 (2020).

${ }^{17}$ Proposal for a Council Directive on a Common Consolidated Corporate Tax Base, COM (2011) 121 final (Oct. 6, 2011) [hereinafter 2011 CCCTB Proposal].

18 European Comm'n Memoranda MEMO/15/5174, The Commission, Questions and Answers on the CCCTB Re-launch (June 17, 2015), https://ec.europa.eu/commission /presscorner/detail/en/MEMO_15_5174 [https://perma.cc/E3J5-3FG6] [hereinafter Q\&A CCCTB].

${ }^{19}$ Consolidated Version of the Treaty of the Functioning of the European Union art. 107, May 9, 2008, 2008 O.J. (C 115) 47.

20 State Aid Control, EUROPEAN COMM'N, https://ec.europa.eu/competition /state_aid/overview/index_en.html [https://perma.cc/7XC3-PCAJ] (last visited July 10, 2020) (identifying tax relief as form of prohibited state aid). 
Whether the target of legislation or a multinational) project is the individual, ${ }^{21}$ the $\mathrm{MNE},{ }^{22}$ or both ${ }^{23}$ the legislative or project objective almost invariably is to measure income and source in a manner that disregards artificial or manipulative sourcing. A frequent indicium of such artificiality or manipulation is a related party transaction where the parties are in different taxing jurisdictions and the pricing shifts profit to low or no-tax jurisdictions. While reallocation of income by the tax collector under existing transfer pricing regulations and guidelines currently is possible, ${ }^{24}$ existing transfer pricing regulations have proven to be inadequate in restraining tax base erosion and accompanying profit shifting. Were existing transfer pricing regulation adequate, the BEPS projects would have been unnecessary. Underlying the reallocation process is the perception that the individual or MNE is manipulating income source and underpaying tax rather than simply paying tax to the wrong jurisdiction. However, with the possible exception of the CCCTB which would apportion the income tax base among the EU countries in which the MNE operates under a uniform set of rules in an endeavor to prevent double taxation and no taxation of income, ${ }^{25}$ an objective shared with most tax treaties, ${ }^{26}$ the international projects developed by the OECD and national anti-avoidance rule ${ }^{27}$ reallocate income to the developed economies with relatively high corporate tax rates ${ }^{28}$ rather than to less developed or developing economies. While the OECD projects purport to be neutral in identifying correct income source, reallocation favors the developed economy jurisdictions. From the OECD approach, one concludes that the underpayment of tax is significant because it deprives the treasury of a developed economy of tax revenue owed to it. If the projects increase the tax revenue of developed economies, however, they are likely to decrease investment that less developed economies may have captured with low taxes and tax incentives.

${ }^{21}$ Foreign Account Tax Compliance Act (FATCA), Pub L 111-147, 124 Stat. 97 (codified as amended in scattered sections of I.R.C. $\S \S 1471-1474,6038 D)$ (imposing penalties and sanctions for failing to report accounts and income of U.S. persons); I.R.C. § 877A (expatriation tax on U.S. persons who relinquish citizenship or permanent residence in the U.S.), for example.

22 See I.R.C. $§ 7874$ (taxing inverting entities that cease to be U.S. entities); 2011 CCCTB Proposal, supra note 17. See also, e.g., BEPS, supra note 16.

${ }^{23}$ See Controlled Foreign Corporation (CFC) provisions under section 951 in the U.S. I.R.C. $§ 951$. See also, for example, similar provisions in other countries taxing some or all corporate income to the corporation's shareholders. Prebble \& Prebble, supra note 6.

${ }^{24}$ Cf. I.R.C. $\$ 482$ ( "[T] $]$ he Secretary may distribute, apportion, or allocate gross income, deductions, credits, or allowances between or among such organizations, trades, or businesses, if he determines that such distribution, apportionment, or allocation is necessary in order to prevent evasion of taxes or clearly to reflect the income of any of such organizations, trades, or businesses"); I.R.C. $\S 59 \mathrm{~A}(\mathrm{~b})$ (the base erosion minimum tax imposing a minimum 10 percent tax on deductible amounts paid between related parties). See also I.R.C. § 267A (the disallowance of deductions in hybrid transactions when not matched with an inclusion).

${ }^{25}$ See 2011 CCCTB Proposal, supra note 17.

${ }^{26}$ Tax treaties include prevention of double taxation among other functions in their title. Reuven S. Avi-Yonah, Double Tax Treaties: An Introduction, in THE EFFECT of Treaties on Foreign Direct Investment: Bilateral Investment Treaties, Double TaXation Treaties and InVESTMENT Flows 99, 99 (K. P. Sauvant and L. E. Sachs eds., 2009).

27 See, e.g., I.R.C. $\$ 951$ (CFC provisions).

${ }^{28}$ High rate of tax is a relative term. The U.S. reduced its corporate income tax rate from a maximum of $35 \%$ to $21 \%$ in 2018 and imposed a maximum rate of $50 \%$ as recently as 1985 . Tax Cuts and Jobs Act (TCJA) of 2017, Pub. L. No. 115-97, 131 Stat. 2054 (codified as amended in scattered sections of I.R.C.); I.R.C. $§ 11$ (1982). See also Federal Corporate Income Tax Rates, Income Years 1909-2012, TAX FounD., https://taxfoundation.org/federal-corporate-income-taxrates-income-years-1909-2012/ [https://perma.cc/JHX6-G9LR]. 
For all taxpayers, including MNEs, the level of taxation may be a key but not the only economic factor in the analysis of where to earn income. Choosing where to locate income-producing activity involves a bundle of economic and non-economic factors. Tax rules often are ambiguous and economically favor certain jurisdictions, but the ambiguity also might lead to multiple tax impositions. Tax rules are not alone in their ambiguity. The location of income-producing activity is also ambiguous, even more so today, when intangible, digital property produces income without any clear link to a specific and identifiable source, even with a single factor of destination of consumption as determinative. Destination is an inadequate proxy for taxing all income insofar as it concentrates income in high consumption destinations. High consumption tends to coincide with a country's level of development because increases in consumption generally correlate with increases in disposable income. ${ }^{29}$ Similarly, residence of the income producer is often uncertain and residence of the owners of an income producing entity may not be more certain as one must unpeel possible layers of ownership. ${ }^{30}$ While taxpayers may complain that the tax rules are uncertain, they exploit the ambiguity of income source to locate income where the level of taxation is lowest rather than where income-producing activity takes place. Splitting genuine economic activity source from tax source enables taxpayers to minimize taxation artificially without there being certainty as to a single genuine source. Competing, legitimate claims of source may belong to multiple jurisdictions. Undoubtedly the income should be taxable somewhere. Ideally, if all income everywhere were subject to identical tax rules and rates, the taxpayer would be indifferent as to income source and would make location decisions based on non-tax factors.

Commentators have expressed concern that enhanced tax capture from MNEs favors the advanced economies unduly. ${ }^{31}$ Those commentators who critique the income shift for taxing purposes to developed economy jurisdictions argue that the BEPS projects fail to allocate a sufficiently large share of the income tax base to less-developed jurisdictions. This literature suggests other "fairer" methods for allocating or apportioning the tax base. One approach recommends a modified view of value creation and suggests allocating more of the base to where value is created. ${ }^{32}$ Another offers a method of formulary apportionment of the income tax base that includes a labor factor in the formula, not as a function of wages, but rather as a function of person-hours of work to prevent wage

${ }^{29}$ See Reuven S. Avi-Yonah, Destination Based Corporate Tax: An Alternative Approach, (Univ. of Mich. Pub. L. \& Legal Theory Rsch, Working Paper No. 529, 2016), https://ssrn.com/abstract=2883835 [https://perma.cc/2VF5-LEUK]; Reuven S. Avi-Yonah \& Kimberly A. Clausing, Problems with Destination-Based Corporate Taxes and the Ryan Blueprint, (Univ. of Mich. Pub. L. \& Legal Theory Rsch, Working Paper No. 16-029, 2017), https://ssrn.com/abstract=2884903 [https://perma.cc/Q2GJ-TJSC]; Wei Cui, Destination-Based Cash-Flow Taxation: A Critical Appraisal, 67 U. TORONTO. L.J. 301 (2017) (critical analysis of destination-based cash flow taxation); Salesfactor.org, Comment Letter on Sales Factor Formulary Apportionment of Global Profits as an Alternative System of Taxation of to the Current U.S. Federal Corporate Income Tax (Apr. 13, 2015), https://www.finance.senate.gov/imo/media/doc/Sales \%20Factor_Redacted3.pdf [https://perma.cc/5CNP-2C3H].

${ }^{30}$ Robert J Peroni, J. Clifton Fleming, Jr. \& Stephen Shay, Defending Worldwide Taxation with a Shareholder-Based Definition of Corporate Residence, 2016 BYU L. REV. 1681, 1683-84 (2016).

${ }^{31}$ See DeVEREUX ET AL., supra note 16.

32 Allison Christians \& Laurens van Apeldoorn, Taxing Income Where Value is Created, 22 Fla. TAX REV. 1 (2018). 
differentials from distorting apportionment formulas in favor of high wage countries. ${ }^{33} \mathrm{~A}$ third would allocate tax base by the benefit received by investment destination rather than the benefit received from the destination by the investor. ${ }^{34}$

The goal for the OECD and the governments in developed economies has been primarily sourcing income to developed economies so that it may be taxed there under that jurisdiction's tax regime. The more general proposition that each MNE (and each individual, as well) should pay an identifiable and specific portion of their income in tax without regard to which nation receives the tax has not been prominent. If worldwide agreement on an ideal amount of tax and uniform tax rules were possible, as this Article will recommend, rather than the sourcing or mis-sourcing of income, the next step would be allocation of the tax revenue among jurisdictions. Artificial sourcing would not alter the amount of tax payable by any taxpayer or related group of taxpayers.

While fairness certainly underlies the OECD's BEPS projects, fairness there has been primarily an income source concept, maintaining that if income is attributable to a source, the source has priority in imposing its tax. Even under the U.S.'s worldwide taxation of its citizens and residents, ${ }^{35}$ the U.S. has ceded taxing authority to the income source country through the foreign tax credit. ${ }^{36}$ Existing concepts of source favor developed economies. Unless some innovative source concept might compensate for imbalances in opportunities and resources worldwide by imputing more level distribution of opportunities and resources and taxing income according to that imputed source, a different manner of allocating worldwide taxing opportunity is critical to enable nonaffluent nations and regions to develop and provide a reasonable standard of living to all people free from need.

It would be a significant conceptual shift to jettison the competitive concept of source as the primary basis for international income taxation and adopt the more nuanced and collaborative needs-based system this Article proposes. Despite the developed economies' income productivity, such a tax system would emphasize non-geographic fairness in the distribution of resources. The international community would unite on tax principles to prevent tax base erosion independent of source taxation so that the principles would not overwhelmingly favor the advanced economies. Instead, the objective of the tax system would be to generate adequate governmental resources to meet worldwide revenue demands. Currently, developed economies devote less than one percent of their tax revenue to development for less developed economies. ${ }^{37}$ International uniformity would require MNEs (and other taxpayers) to pay some reasonable amount of tax on their income and facilitate devotion of a larger amount of tax revenue to international development.

The focus of the tax principles would be on the question of whether a definable, correct set of tax rules might exist under which each taxpayer pays a "fair" amount of tax without regard to the jurisdictions in which the taxpayer operates. This Article emphasizes

${ }^{33}$ Henry Ordower, Utopian Visions Toward a Grand Unified Global Income Tax, 14 FLA. TAX REV. 361, 387 (2013) (labor factor in the income apportionment formula based on person hours of work rather than payroll amounts).

${ }^{34}$ Vasiliki Koukoulioti, The Benefit Principle Revisited - Avoiding the Repercussions of Digitalization on the TaxBase Sustainability (May 29, 2020) (unpublished Ph.D. dissertation in process, Queen Mary, University of London) (on file with author).

${ }^{35}$ See I.R.C. § 61; Treas. Reg. § 1.1-1(b) (taxing U.S. citizens and residents on their income from all sources worldwide).

${ }^{36}$ I.R.C. $\S 901(a),(b)(1)$.

${ }^{37}$ Alexis Brassey \& Henry Ordower, The Village of Billionaires: Fair Taxation and Redistribution Amid Relative and Absolute Poverty, 99 TAX NoTES INT'L 97 (July 6, 2020). 
the question of whether, assuming a "fair" measure of tax exists, distribution of that "fair" amount among jurisdictions ought to follow determinations of need with the elimination of suffering - starvation, disease, homelessness - at the forefront rather than the place of production of income. The imposition of tax can be along ability to pay principles, while distribution would follow contextualized need. This Article recommends abandoning the premise that income and accompanying tax revenue, however it is measured, be allocated to where the income is produced, in favor of allocating tax revenue based on a broad, inclusive view of revenue that is need-determined to accommodate the systemic transition. Developed economies would continue to have the greatest needs to meet their existing commitments and maintain existing infra- and superstructures. Yet, the shift in distribution principles would help address the uneven worldwide distribution of resources and level disparities between affluent and non-affluent taxpayers and communities, especially those disparities resulting in the absolute poverty prevalent in some parts of the world that generate little income. ${ }^{38}$ The revised system would preclude MNEs from using their economic bargaining power to negotiate tax relief from developing economies that cannot replace the lost revenue easily.

The common assertion by representatives of MNEs that MNEs do not seek to reduce their taxes artificially, ${ }^{39}$ but plan the placement of their income to avoid becoming subject to tax on the same unit ${ }^{40}$ of income in multiple jurisdictions is consistent with uniform tax rules and a fair rate of tax. Source planning may also protect MNEs from suffering a tax-based, competitive disadvantage. As long as the MNE does not pay tax while its competitors avoid tax leaving the MNE at a competitive disadvantage, the MNEs are indifferent to reasonable levels of taxation. Transparent and uniform tax rules would enable the MNEs to determine their tax liability to each jurisdiction correctly. Uniform rules would require the MNEs' competitors to similarly pay a correct amount of tax to each jurisdiction. Taxpayers should not be subject to non-uniform tax rules in any taxing jurisdiction. ${ }^{41}$ Yet, even if tax rules and rates are uniform within a taxing jurisdiction, they are not currently uniform across jurisdictions, and MNEs deploy considerable resources to minimizing their taxes whether as a competitive defense or as profit-centered activity. ${ }^{42}$

\footnotetext{
${ }^{38} I d$.

${ }^{39}$ Ryan Finley, Uber Accepts Need for New International Tax System, TAX NoTES TODAY

Glob. (June 26, 2020), https://www.taxnotes.com/tax-notes-today-international/digitaleconomy/uber-accepts-need-new-international-tax-system/2020/06/26/2cnmn?highlight=Pillar \%201 [https://perma.cc/U3RM-L4W5]; Adrian Weckler \& Michael Cogley, 'No one did anything wrong here and Ireland is being picked on... It is total political crap' - Apple chief Tim Cook, INDEPENDENT.IE (Sept. 1, 2016), https://www.independent.ie/business/irish/no-one-did-anythingwrong-here-and-ireland-is-being-picked-on-it-is-total-political-crap-apple-chief-tim-cook-

35012145.html [https://perma.cc/XLE9-84P5]. In a recent ruling by the General Court of the European Union, the Court overruled the EC's decision as the Court found that the EC had not met the legal standard necessary to show that there was an economic advantage (state aid) as required by Article 107(1) TFEU. See Case T-778/16 and T-892/16, Ireland v. European Comm'n, 2020 E.C.L.I. 338.

${ }^{40}$ Except when referring to specific U.S. tax provisions for which the U.S. dollar will be used, "unit" of income is the income measured in the functional currency of the income producing entity.

${ }^{41}$ When taxing rules do not treat all taxpayers the same, the taxing state is discriminating among taxpayers, a possible violation of the state aid prohibition in the EU if the taxpayers are residents or nationals of different states. TFEU art. 107. Likewise, states may not discriminate between residents and non-residents in the U.S. Hooper v. Bernalillo Cty. Assessor, 472 U.S. 612 (1985).

${ }^{42}$ Henry Ordower, The Culture of Tax Avoidance, 55 ST. LouIs U. L.J. 47 (2010).
} 
Harmonization of taxation internationally under the rubric of a universally correct level of tax is elusive. Efforts to achieve consensus on combatting tax avoidance may lead to some multi-national agreements, but if each signatory gets to apply its own tax rules and interpretations to the agreement, the force of the agreement diminishes. National sovereignty remains a formidable, albeit primarily rhetorical, ${ }^{43}$ barrier to the best resolution of many issues common to most nations. The recent COVID-19 pandemic illustrates the difficulty of attaining international consensus on any matter; as little consensus exists even on a common authority to combat a health threat to the entire world population. The pandemic did not elicit an international call to deputize an existing World Health Organization to design a method to contain the spread of the virus. Rather, each nation and often each governmental sub-unit took its own politically determined approach with considerable but limited harmonization of methods. On the tax side, the EU, despite being a remarkable voluntary union of sovereign and historically often warring nations, has failed to harmonize taxes except in setting a minimum value-added tax rate with incompletely harmonized operating rules. ${ }^{44}$ The EU itself as a governmental unit lacks the power to tax, although a nascent movement to grant limited taxing authority to a central EU government along with a U.S.-type federalist model of overlapping state and central taxing authority has begun to gather support among leading tax academics. ${ }^{45}$ The task of broad-based harmonization is formidable.

Like an earlier article recommending the creation of an international taxing agency to apportion a global income base, ${ }^{46}$ this Article argues that national sovereignty and national self-interest remain impediments to fair taxation and must yield to the international need for predictable taxation at a level fair to all. The Article recommends modified international tax rules administered by a single international agency that collects and distributes income tax revenue among sovereign states based on the contextualized revenue needs of each state under international fairness-based principles. ${ }^{47}$ This Article inquires whether the developed economies might deploy fairer tax revenue distribution to persuade less developed economies to abandon tax competition and suggests possible coercive devices to nudge voluntary abandonment of tax competition. ${ }^{48}$

${ }^{43}$ Rhetorical insofar as the World Trade Organization (WTO) and other international bodies cannot function successfully without relinquishment of national sovereignty. $C f$. discussion infra Part V.

${ }^{44}$ Council Directive 2006/112, 2006, 2006 O.J. (L 347) 1 (EC) [hereinafter EC Council Directive]. There also has been some harmonization on a few customs matters. See Regulation 952/2013 of the European Parliament and of the Council of 9 October 2013 Laying Down the Union Customs Code 2013 O.J. (L269) 1.

45 See Op-Ed: European Solidarity Requires EU Taxes, EU L. Live (Apr. 21, 2020), https://eulawlive.com/op-ed-european-solidarity-requires-eu-taxes/ [https://perma.cc/K562-MD2T]; Frans Vanistendael, Apple: Why the EU Needs a Common Corporate Income Tax, 99 TAX NoTES INT'L 451 (July 27, 2020).

${ }^{46}$ Ordower, supra note 33.

${ }^{47}$ Brassey \& Ordower, supra note 37.

${ }^{48}$ Alongside this paper's proposal stands another somewhat more limited impingement on national sovereignty in the form of a recent proposal for a uniform global excess profits tax to complement national taxation of MNEs. Tarcisio Diniz Magalhaes \& Allison Christians, Rethinking Tax for the Digital Economy After COVID-19, 10 HARV. Bus. REV. (forthcoming 2021), https://ssrn.com/abstract=3635907 [https://perma.cc/DT4X-8M5S]. 
III.

\section{REGIONALISM AND TAXING JURISDICTIONS}

With an estimated population of just under one million, ${ }^{49}$ St. Louis County, Missouri has eighty-nine independent municipalities with taxing authority, and the county itself also may tax. Taxing authority is derivative of the state of Missouri's taxing power ${ }^{50}$ guaranteed by the U.S. constitution. ${ }^{51}$ The St. Louis County Collector of Revenue is responsible for billing and collecting ad valorem real and personal property taxes for over two hundred taxing districts in St. Louis County. ${ }^{52}$ The number of taxing districts is more than twice the number of municipalities because the school, fire protection, sewer, and municipal taxing districts are not co-extensive with municipalities but overlap in somewhat mysterious and often historically determined ways, such that multiple school-taxing districts, for example, may overlap the borders of a single municipality. Some districts are funded better than others because real estate is more valuable in some parts of the county and yields greater sums of real property tax revenue ${ }^{53}$ than in other parts, and some municipalities have more retail space generating more sales tax revenue than do others. The state administers sales tax collection and distribution.

An owner of real property in St. Louis County examining their real estate tax bill finds a confusing array of taxing districts imposing a portion of the total tax consolidated into a single invoice. That array often differs from one property to another as district borders for differing types of taxing districts do not coincide. Rates of tax also differ among similar types of districts. The tax base, however, is uniform. Each property has a value attributed to it, and each taxing district within which that property lies applies its tax rate to that uniform value in determining the tax to impose. There is occasionally some ambiguity when a multiple-use property is involved in determining what portion of the property ought to be assessed at the commercial rather than the residential percentage and appraised values of any property may be contested. The rules are uniform for assessing, collecting, and distributing tax among taxing jurisdictions. The County administers the tax, collects the tax payment, and is responsible for sanctions for non-payment including seizure and sale of the property to collect unpaid taxes. Taxing districts neither administer the tax, determine the value of the taxed property nor control sanctions for non-payment.

Uniformity in administration and collection is not unusual worldwide. The U.S. is exceptional in the range of governmental units that have their own administrative infrastructures devoted to tax collection. ${ }^{54}$ Most countries administer and collect income

49 St. Louis County, Missouri, U.S. CENSUS, https://www.census.gov/quickfacts /stlouiscountymissouri [https://perma.cc/G8P4-DKQH].

${ }^{50}$ Mo. Const. art. X, $\S 1$.

${ }^{51}$ U.S. Const. amend. X.

52 See Collector of Revenue, ST. LouIS CNTY. Gov., https://www.stlouisco.com /YourGovernment/CountyDepartments/Revenue/CollectorOfRevenue [https://perma.cc/2VVDH2QL] (last visited July 10, 2020).

${ }^{53}$ Real property taxes are generally a percentage of the value of the property taxed under rules that base the tax on an assessed value lower than the fair value of the property. For example, the assessment formula in Missouri for residential property uses $19 \%$ of the appraised value of the property as the base for real property tax. The percentage used for commercial property is $32 \%$ and the percentage used for farm property is $12 \%$. Mo. STATE TAX COMM'N, PROPERTY REASSESSMENT AND TAXATION PAMPHLET 4 (2017), https://stc.mo.gov/wp-content/uploads/sites/5/2017/01 /Property-Reassessment-Pamphlet-1-18-16.pdf [https://perma.cc/K5YS-7FZX] (last visited July 10, 2020).

${ }^{54}$ Each state of the U.S. has its own taxing agency responsible for state income and consumption taxes and municipalities and other taxing districts with their own agencies are not unusual. See State Tax Agencies, FED'N TAX ADM'R, https://www.taxadmin.org/state-tax-agencies 
taxes, value-added taxes, and often property taxes, centrally. ${ }^{55}$ Rates of tax and property values may vary regionally, but the central authority distributes the tax collected among the regional governmental units providing services and often has responsibility for the enforcement of taxes, even if local governments determine the expenditure of the tax collected.

While the taxing district may set the rate applicable to the taxed property in St. Louis County, state constitutional tax limitations require a public vote before a taxing district may increase a tax rate, ${ }^{56}$ and initiatives to increase a tax might succeed in one district but fail in another overlapping district. The multiplicity of rates and countydetermined property values means that the governmental services in one location may differ significantly from the services in another geographically proximate area within the County. Similarly, with respect to the state-administered sales tax, purchases of identical items at identical prices in two stores near one another often incur different sales tax amounts because the sales tax rates in proximate jurisdictions may differ. Rates of tax are not harmonized, but the state constitution limits the rates municipalities and other taxing districts may impose. ${ }^{57}$ The legislature may impose other limitations on permissible rates separate from the constitutional limitations. ${ }^{58}$

The result of multiple taxing jurisdictions in a relatively small geographic area ${ }^{59}$ is visible in the levels of school funding that impact the educational services for children in St. Louis County. ${ }^{60}$ Some public-school districts become desirable places to live because they offer well-funded, high-quality public education while others are lacking in quality and even may fail to meet state educational standards. ${ }^{61}$ Educational disparities across St.

[https://perma.cc/Y5YV-9U4L]. For example, the city of St. Louis is not part of St. Louis County and has its own collector of revenue responsible for the city earnings tax as well as ad valorem property taxes. See supra note 52.

55 The EU member states collect most or all taxes centrally even where sub-jurisdictions impose differing rates in addition to the national rate. See About Us, HM REvENUE \& Customs, https:/www.gov.uk/government/organisations/hm-revenue-customs/about (last visited June 26, 2020) (UK's central tax, payments and customs authority); Institutional Information, AGENCIA TRIBUTARIA, https://www.agenciatributaria.es/AEAT.internet/en_gb/Inicio/La_Agencia_Tributaria /Informacion_institucional/Informacion_institucional.shtml [https://perma.cc/Q3AL-PF2V] (last visited June 26, 2020); Irish Tax and Customs, REvEnUE COMM'RS, https://www.revenue.ie/en/corporate/information-about-revenue/role-of-revenue/core-business.aspx [https://perma.cc/7SR5-RJLF] (last visited June 26, 2020).

${ }^{56}$ See Mo. Const. art. X, § 22; see also Ariel Jurow Kleiman, Tax Limits and the Future of Local Democracy, 133 HARV. L. REV. 1884 (2020).

${ }^{57}$ See Mo. Const. art. X, $\S \S 8,11$ (limiting rates of tax on personal property and real property, respectively).

${ }^{58}$ See Mo. Const. art. X, $\S 10(\mathrm{c})$ (power of the legislature to limit tax).

${ }^{59}$ See, for example, St. Louis County, which is less than one percent of the land area of Missouri but has nearly 20 percent of the Missouri state population and more than three percent of the state's 6,000 special taxing districts. Sales Tax Jurisdiction Maps, Mo. Dep't of Revenue, https://mogov.maps.arcgis.com/apps/MapSeries/index.html?appid=22cc45ec926e4f94a1f41027b1b edb0e [https://perma.cc/6M5P-E9D8] (last visited July 10, 2020).

${ }^{60}$ Quality of education of course is not solely a function of funding, but better funding generally contributes to a better educational product.

${ }^{61}$ In 2019, the County school districts of Brentwood and Jennings represent the extremes. Measured by dollars per average daily attendance, Brentwood with $\$ 19,035$ had nearly twice the funding of the Jennings district with \$10,676. Building Level Per Pupil Expenditures 2019 Report, Mo. DEP'T OF ELEMENTARY \& SECONDARY EDUC., https://stateofmissouri.app.box.com/s /1nvymfovyruscbmcte1b8dn838mpndlh/file/573737767611 [https://perma.cc/3S2Q-AZYM] (last visited June 17, 2020) [hereinafter 2019 Building Level Expenditure Report]. Brentwood is a midcounty district with a predominantly white enrollment. Jennings is a north county district with a 
Louis County are significant. In several municipalities, children living on opposite sides of a street go to schools in different school districts and may have quite different educational experiences from one another because one school district has greater resources from tax revenue than the other. The school district disparities are somewhat selfperpetuating in that the perceived school district quality affects property values, causing prices of single-family residences in better school districts to be greater than in lower quality districts. Since real estate taxes are based on property value, higher value yields more revenue, sometimes even if the tax rate is lower than in the lower quality school district.

Where resource disparities exist among school districts, disparities in educational quality tend to follow, often along racial lines. In Brown v. Board of Education of Topeka ${ }^{62}$ the U.S. Supreme Court rejected the notion that segregated education could provide equal education and prohibited purportedly "separate but equal" schools. Remedies to level opportunities for children have proved elusive. In some states, federal courts have intervened to address some educational disparities by ordering busing of students across districts to remedy imbalances in the racial composition of student bodies and afford lower-income people - often people of color - better educational opportunities in districts that historically had little or no racial diversity. ${ }^{63}$ To settle a lawsuit, St. Louis County school districts beginning in 1982 initiated a voluntary program busing black students from overwhelmingly black St. Louis City schools to predominately white schools in St. Louis County. ${ }^{64}$ Revenue sharing among districts or consolidation of districts so that all pupils, even in a small county like St. Louis, are covered by identical amounts of tax revenue per student has not gained sufficient political support, even though uniform tax rules and centralized revenue collection would facilitate level revenue distribution. The state of Missouri supplements school funding based on funding need but it has not sought to level funding among districts. ${ }^{65}$

School district boundaries are not an immutable characteristic of each pupil. People may move from one school district to another. While economic barriers to relocation may exist and, accordingly, relocation may be difficult, better-paying employment could open the door to relocation. The better-funded school district may not prevent the family from the less funded district from moving across the street to the better-

predominantly black enrollment. Brentwood School District, PuB. ScH. ReV., https://www .publicschoolreview.com/missouri/brentwood-school-district/2905880-school-district

[https://perma.cc/MC6G-DQ7L] (last visited June 26, 2020) (63\% white enrollment as of 2020); Jennings School District, GREAT SCH., https://www.greatschools.org/missouri/saint-louis/jenningsschool-district/ [https://perma.cc/T2DF-BLRF] (last visited June 26, 2020) (98\% Black enrollment). ${ }^{62}$ Brown v. Bd. of Educ. of Topeka, 347 U.S. 483 (1954).

63 Swann v. Charlotte-Mecklenburg Bd. of Educ., 402 U.S. 1 (1971) (establishing authority of courts to order busing to remediate educational segregation).

${ }^{64}$ Ryan Delaney, St. Louis school desegregation program begins its long wind down, ST. LOUIS PUB. RADIO (Nov 1, 2018) https://news.stlpublicradio.org/post/st-louis-school-desegregationprogram-begins-its-long-wind-down\#stream/0 [https://perma.cc/DK9U-KS9W].

${ }^{65}$ See, e.g., 2019 Building Level Expenditure Report, supra note 61. 
funded district, ${ }^{66}$ a right that is not available across national borders. ${ }^{67}$ If, however, too many lower-income individuals move to the more affluent school district, the existing residents may choose to limit tax revenue and reject any tax increase, diminishing the quality of the public schools. Those longer-term, affluent residents who do not relocate may establish private schools for their children that exclude the new residents through high costs that often serve as a proxy for prohibited racial discrimination in public education. ${ }^{68}$

No active discussion is underway in St. Louis County to level tax revenue distribution countywide to eliminate the disparities in school quality and other governmental services. Instead of generous cooperation among taxing districts, there is tax-based competition among governmental units. In St. Louis County, municipal governments seek to annex unincorporated areas of the county along major thoroughfares where commercial development and concomitantly sales tax revenue is projected to grow. ${ }^{69}$ Negotiation between private developers and governmental units for investment in new or renovated facilities that might bring employment and future tax revenue occurs on the level of temporary, sometimes long-term, tax concessions. Tax concessions, however, undermine the ability of state and local governmental units to generate revenue to support necessary government services when state constitutional tax limitations already make necessary tax increases troublesome. Concessions to new and existing business interests require additional taxes on non-affluent residents or a diminution of services. Governmental units have utilized extra-taxing power, revenue-raising to supplement limited tax revenue. User fees have substituted for government services historically funded with general revenue. ${ }^{70}$ In St Louis County, several municipal governments have resorted to predatory, revenue-based policing by aggressively enforcing municipal ordinances, especially traffic rules, to collect fines and court fees from non-affluent violators to supplement tax revenue. ${ }^{71}$

While tax concession competition has played an investment role in the U.S. for many years ${ }^{72}$ it has become particularly robust during recent decades. MNEs actively

${ }^{66}$ There is a constitutional right to travel and reside without restriction in the U.S. See Crandall v. Nevada, 73 U.S. (6 Wall.) 35 (1868) (state cannot impose restriction on personal right to travel); Shapiro v. Thompson, 394 U.S. 618, 629-31, 638 (1969) (welfare benefits may not be conditioned on duration of residency); Dunn v. Blumstein, 405 U.S. 330, 338-42 (1972) (durational residency requirements for voting).

${ }^{67}$ Despite their proximity, relocation from Ciudad Juarez, Mexico to El Paso, Texas requires a U.S. visa to enter and reside unless one is a U.S. citizen or permanent resident. See Brassey \& Ordower, supra note 37, at 112-13.

${ }^{68}$ See Brown, 347 U.S. 483.

${ }^{69}$ Boundary Commission of St. Louis County reviews proposal for annexation and consolidation. See Boundary Comm'n, St. Louis CNTY., Mo., https://www.boundarycommission .com/ [https://perma.cc/WU2W-KTVD] (last visited July 10, 2020).

${ }^{70}$ See Kleiman, supra note 56; Jasper L. Cummings, Jr., User Fees Versus Taxes, TAx ANALYSTS (Nov. 4, 2011), http://www.taxhistory.org/www/features.nsf/Articles /27F622B404B089F68525793E00536946?OpenDocument [https://perma.cc/H6V6-MC6N] (last visited July 10, 2020).

${ }^{71}$ Henry Ordower, J.S. Sandoval, \& Kenneth Warren, Out of Ferguson: Misdemeanors, Municipal Courts, Tax Distribution and Constitutional Limitations, 61 How. L.J. 113 (2017).

72 See Robert S. Chirinko and Daniel J. Wilson, Tax Competition Among U.S. States: Racing to the Bottom or Riding on a Seesaw? (Fed. Rsrv. Bank S.F., Working Paper 2008-3), https:// www.frbsf.org/economic-research/files/wp08-03bk.pdf [https://perma.cc/8HX5-5ASU]; Henry Ordower, Les Impôts Relatifs aux Investissements Étrangers aux États-Unis d'Amérique (Observations Générales), 1996-2 Revue InTERnATIONALE DE DroIT ECONOMIQUE 185-201 (1996) (includes discussion of negotiated state or local tax concessions). 
solicit bids from governments when they are evaluating where to locate a new or expanded facility. ${ }^{73}$ Governmental units offer tax concessions as all or a portion of their proposal to entice the business decision-makers to invest in the geographic area and bring jobs and collateral businesses to the governmental unit. Tax concession competition sometimes even becomes destructive as the commercial development consumes governmental resources without contributing adequately to tax revenue. Occasionally, the business attracted with special tax concessions and other subsidies relocates when the period of the tax concession expires and leaves the governmental unit with facilities that cannot be adequately utilized. For example, in the case of the Rams, a National Football League franchise, St. Louis directly and indirectly used tax revenue to provide a stadium. When the stadium no longer met stadium quality conditions included in the lease, the Rams became free to abandon the St. Louis area. ${ }^{74}$ Business demand for tax-based government contributions has become an important-possibly indispensable-feature of major developments throughout the U.S. When governmental offers are insufficient, the businesses go elsewhere. Amazon, for example, negotiated a variety of subsidies, including tax subsidies from New York City, but when local elected officials began to object due to the cost to the City, Amazon abandoned its plans to locate a facility in New York City. ${ }^{75}$ More egalitarian tax revenue distribution across borders might render tax concession competition obsolescent as well as unnecessary.

The U.S. has substantial competition across taxing districts and a confusing profusion of taxing units and tax bases, so that items included in one tax base frequently become subject to tax under another base as well. Income may be subject to a federal income tax, a wage income tax (social security), a state income tax, and a local (wagebased) income tax, and the income remaining after the income taxes may become subject again to a consumption tax when the taxpayer deploys it for purchases and an annual property tax following purchase. Each tax competes for its share of overall tax revenue. Part of the competition among jurisdictions may be the absence of one of the taxes. Florida and Texas, for example, impose no individual state income tax. ${ }^{76}$ Alaska, Delaware, Montana, New Hampshire, and Oregon impose no sales tax. ${ }^{77}$ Tax competition allows private parties to allocate a portion of what should be tax revenue to themselves. Tax increment financing, for example, dedicates incremental tax revenue from a private development to repayment of indebtedness incurred to fund construction of public

${ }^{73}$ See, e.g., Nick Wingfield, Amazon Chooses 20 Finalists for Second Headquarters, N.Y. TiMES (Jan. 18, 2018), https://www.nytimes.com/2018/01/18/technology/amazon-finalistsheadquarters.html [https://perma.cc/Y948-BW5V].

${ }^{74}$ See, e.g., Robin Respaut, With NFL Rams Gone, St. Louis Still Stuck with Stadium Debt, REUTERS (Feb. 3, 2016), https://www.reuters.com/article/us-sports-nfl-stadiums-insight/with-nflrams-gone-st-louis-still-stuck-with-stadium-debt-idUSKCN0VC0EP $\quad[$ https://perma.cc/E86HHVV3].

75 See, e.g., Scott Cohn, Amazon reveals the truth on why it nixed New York and chose Virginia for its HQ2, CNBC (July 10, 2019), https://www.cnbc.com/2019/07/10/amazon-revealsthe-truth-on-why-it-nixed-ny-and-chose-virginia-for-hq2.html [https://perma.cc/QMV7-XM9J] (Amazon withdrew from New York City when city council members balked at size of the tax concessions); Jacob Passy, This Is What Amazon's "HQ2" Was Going to Cost New York Taxpayers, MARKETWATCH (Feb. 16, 2019), https://www.marketwatch.com/story/what-amazons-hq2-meansfor-taxpayers-in-new-york-and-virginia-2018-11-14 [https://perma.cc/ZQM6-FCX9].

${ }^{76}$ See also Julie Roin, Changing Places, Changing Taxes: Exploiting Tax Discontinuities, Symposium on Legal Discontinuities 28 (Univ. of Chi. Pub. L. Working Paper, Paper No. 740), https://papers.ssrn.com/sol3/papers.cfm?abstract_id=3587056 [https://perma.cc/TNS8-QVMS].

77 What States Impose Sales/Use Tax? SALES TAX Inst., https://www.salestaxinstitute.com /sales_tax_faqs/what_states_impose_sales_use_tax [https://perma.cc/2JVE-BWHT]. 
improvements necessary to service the private development. Absent the tax increment financing, the private developer would be responsible for the cost of the public improvements because those improvements are required to accommodate the development. ${ }^{78}$ Similarly, the charitable contribution deduction ${ }^{79}$ enables taxpayers to allocate a portion of a taxing unit's revenue to other private interests rather than leaving the revenue distribution to the government officials charged with distributing the public purse. In the case of charitable contributions, the private interests are charities of the donor's choice, rather than governmentally selected functions. ${ }^{80}$

Tax concessions often mean that those best able to pay taxes are not required to pay. Tax concessions do not necessarily reduce tax revenues for the taxing unit granting the concessions. If the new business activity did not exist in the taxing unit previously, it was not generating tax revenue. Nevertheless, business development frequently increases demand for governmental services and concomitantly the need for tax revenue to pay for the services. Funding the services may require property owners, other than those receiving concessions, to pay increased property taxes if the business draws additional residents and concomitant demand for public schools. Alternatively, an increased population increases sales tax revenue as greater revenue demands may be met with additional sales and use taxes to carry the increased tax burden at the expense of those with moderate income. In locales like Missouri subject to statutory or constitutional tax limitations requiring voter approval for tax increases, if California and Missouri are representative, voters approve rate increases for sales taxes more frequently than property taxes, even though property taxes tend to be less regressive relative to income or wealth than sales taxes. ${ }^{81}$ Moreover, increased consumption tax revenue may not flow from the increased business activity, as the dedication of consumption tax revenue from the new business activity to the business' facilities or debt servicing may be among the concessions. ${ }^{82}$ Facilities for product distribution produce relatively little incremental consumption tax revenue locally as the consumption taxes are collected and paid to the taxing authority where the purchaser receives and uses the product, if at all. ${ }^{83}$ Jurisdictions that collect income or payroll taxes

${ }^{78}$ Tax Increment Financing: The Basics, NAT'L Hous. CONF., https://nhc.org/policyguide/tax-increment-financing-the-basics/ [https://perma.cc/BAQ8-H3XJ].

${ }^{79}$ See I.R.C. § 170(a)(1).

${ }^{80}$ See Henry Ordower, Charitable Contributions of Services: Charitable Gift Planning for Non-Itemizers, 67 TAX L. 517, 533-36 (2014).

81 See Mac Taylor, Legis. Analyst's OfF., A Look at Voter-Approval REQUIREMENTS FOR LOCAL TAXES 11 (2014), https:/lao.ca.gov/reports/2014/finance/localtaxes/voter-approval-032014.pdf [https://perma.cc/3FAE-YQBP] (greater approval rate for taxes like sales taxes that do not require a super majority in California). See also Taxes on the Ballot, BALlotPEDiA, https://ballotpedia.org/Taxes_on_the_ballot [https://perma.cc/HT87-MNW8] (Missouri tax provision ballots on general and property tax increases).

82 This is a common concession for servicing indebtedness on professional entertainment facilities, including stadiums, as well as warehouses and distribution centers like Amazon. Arlington's Record Sales-Tax Revenue Will Pay Off Cowboys Stadium Debt Years Early, DaLl. MoRnING News (Nov. 21, 2012), https://www.dallasnews.com/news/2012/11/22/arlington-s-recordsales-tax-revenue-will-pay-off-cowboys-stadium-debt-years-early/ [https://perma.cc/5YA9-4EMU] (record sales tax revenue rise allows city leaders to pay off the stadium debt early). See also Alicia Robinson, Stadium Maintenance, Debt Eat into Anaheim's Revenue from Hosting Angels Baseball, ORANGE CNTY. Reg. (Sept. 25, 2019), https://www.ocregister.com/2019/09/25/stadiummaintenance-debt-eat-into-anaheims-revenue-from-hosting-angels-baseball/ [https://perma.cc/2NGP-FP2X].

${ }^{83}$ South Dakota v. Wayfair, Inc., 138 S. Ct. 2080 (2018) (expanding the authority of states to require vendors with no physical presence in the state to collect and pay over the sales or use tax on items sold to state residents). Sales taxes are add-on taxes imposed when personal property is 
may derive additional revenue from the workers at the new facility, but in many instances those workers are not new but have changed employment. Where the workers are new taxpayers in the jurisdiction, they seem likely to be predominantly moderate to low-income workers because the facilities may require warehouse, maintenance and concession labor in greater numbers than highly compensated management employees. ${ }^{84}$ Taxes applicable to them are often flat or regressive rather than progressive. ${ }^{85}$ In addition, part of the federal income tax is imposed separately on wages and self-employment income and is regressive because of its wage cap and its limitation to income from services. ${ }^{86}$

The growing disparity in wealth between affluent and non-affluent residents of the U.S. has been attributed in part to taxation. ${ }^{87}$ Proposals to introduce or expand progressivity in taxation to impose a greater tax burden on affluent taxpayers or to impose a tax on wealth have found proponents among members of Congress who would deploy the revenue to improve services and living conditions for the less affluent members of the society. ${ }^{88}$ Those senators have not garnered adequate political support for their positions to enact the changes. Recent analysis by a group of economists addressing recovery from the economic impact of the 2020 pandemic instills new force into the wealth tax and withdrawal or freezing of tax benefits for successful businesses. ${ }^{89}$ Even if enacted,

purchased for consumption rather than resale. The vendor generally collects the tax and pays it over to the state. If the vendor sells to a purchaser in another state, the purchaser becomes liable to the other state for complementary use tax. Collection of use tax is difficult unless the vendor collects and pays over the tax. Until the Wayfair decision, states could not require a vendor to collect use tax on sales into the state unless the vendor had a direct or indirect presence there. The Wayfair decision removed the physical presence requirement for vendors with substantial sales into a state so that a state may require out of state vendors to collect their use tax and pay it over less a fee for their collection services. The state of Missouri has not yet enacted legislation implementing the Wayfair decision for sales into Missouri. See Hannah Meehan, Sales Tax for Remote Sellers: Missouri's Response in A Post-Wayfair World, ST. LouIS U. L.J. OnLINE 23, https://scholarship.law.slu.edu /cgi/viewcontent.cgi?article=1001\&context=lawjournalonline [https://perma.cc/9MC5-UW9M].

${ }^{84}$ Stadiums may be an exception if they are built to house a professional sports business employing many highly compensated athletes.

${ }^{85}$ Like earnings taxes in a number of cities, St. Louis City Earnings Tax is imposed on income from services only at a flat rate of 1 percent and is regressive because it does not tax investment income. See ST. LouIs, Mo., Mun. CodE Ch. 5.22, https://library.municode.com /mo/st._louis/codes/code_of_ordinances/364861?nodeId=RECOSALO2020AN_TIT5REFI_CH5.2 2EATA $[$ https://perma.cc/J33R-39TT].

${ }^{86} \mathrm{See}$, for example, social security tax in the U.S. that is imposed at a flat rate on wages (not income from investment or business ownership) up to a ceiling amount of $\$ 137,700$ in 2020 and then zero for wages in excess of that ceiling. See Social Security and Medicare Withholding Taxes, IRS, https://www.irs.gov/taxtopics/tc751 [https://perma.cc/WD4R-YDX2].

${ }^{87}$ See Emmanuel Saez \& Gabriel Zucman, The Triumph of InJustice: How the Rich Dodge TaXes and How to Make Them Pay (2019); Emmanuel Saez, Striking it Richer: The Evolution of Top Incomes in the United States 6 (Mar. 2, 2019) (unpublished manuscript), https://eml.berkeley.edu/ saez/saez-UStopincomes-2017.pdf [https://perma.cc/FF6MRT3Z]; The Distribution of Household Income, 2016, Cong. BudGET OFF., https://www.cbo.gov /publication/55413 [https://perma.cc/J2Z5-EKQF] (July 9, 2019); Henry Ordower, Taxes and Inequality, in InEQuality in America: CAuSes AND Consequences of THE Rich Poor Divide (Kimberley L. Kinsley \& Robert S. Rycroft eds.) (forthcoming 2021).

${ }^{88}$ Neil Irwin, Elizabeth Warren Wants a Wealth Tax. How Would That Even Work?, N.Y. Times (Feb. 18, 2019), https://www.nytimes.com/2019/02/18/upshot/warren-wealth-tax.html [https://perma.cc/835F-6QH2]; Huaqun Li \& Karl Smith, Analysis of Sen. Warren and Sen. Sanders' Wealth Tax Plans, TAX Found. (Jan. 28, 2020), https://taxfoundation.org/wealth-tax/ [https://perma.cc/835F-6QH2].

89 IndeP. COMM'N FOR ReForm InT'L CORP. TAX'N, The Global PANDEMic, Sustainable ECONOMIC RECOVERY, AND INTERNATIONAL TAXATION (2020), https://static1.squarespace.com 
however, no one is proposing distribution of increased tax revenue beyond the borders of the relevant taxing unit-whether that unit is a specialized, municipal, state, or national unit. A school taxing district in St. Louis County is not sharing revenue with another school taxing district, nor a state like Missouri sharing revenue with a neighboring state like Arkansas, nor the U.S. sharing revenue with Mexico. Residents of one U.S. jurisdiction may move freely to another U.S. jurisdiction with a better tax base and better governmental services, for example, between lesser and better funded St. Louis County school districts or across state lines if they have the wherewithal to change their residence. On the other hand, if the better-funded school district is in El Paso, Texas, and the lesser funded district in Ciudad Juarez, Mexico, moving to the better-funded district is problematic even if the distance from one to the other is small. The existence of national borders as a barrier to opportunity renders the argument for cross-border revenue distribution even more compelling than cross-district where the individual may choose to relocate and capture access to the better funded district. Even within the U.S., however, ability to relocate is circumscribed by individual economic factors including employment and accumulated wealth. ${ }^{90}$

The concept of sovereignty supports respecting a taxing unit's choice to spend the tax revenue it manages to collect, even where the tax base is produced by activities in other places. A product manufactured in Illinois but sold to Missouri consumers is subject to Missouri consumption tax, as a product manufactured in Mexico but transported to and then sold to U.S. consumers is subject to consumption taxes in the U.S., not Mexico. Illinois or Mexico in the examples derive no benefit from the consumption tax on sale. Illinois and Mexico might encourage their local vendors to assist purchasers in Missouri or the U.S., respectively, to avoid Missouri or other U.S. consumption taxes by shipping items directly to consumers in the other jurisdiction free from the consumption tax. ${ }^{91}$ Any benefit Illinois or Mexico derives from increased business activity locally, even if minimal, is nevertheless more than it would have received from the consumption tax imposed by a neighboring jurisdiction. Sovereignty is a political shield that fails to take unequal distribution of wealth and resources into account.

Despite central collection and administration in St. Louis County or, with respect to consumption taxes, the state of Missouri, sharing revenue across taxing unit borders remains bewilderingly difficult no matter how geographically close or closely connected the communities may be, how similar the residents are to one another, and how unequal the revenue distribution may be. Leveling revenue distribution to provide comparable services and opportunities throughout St. Louis County seems a desirable fairness objective. Even within St. Louis County's narrow governmental overlay of central collection and administration under uniform taxing rules and with a uniform tax base, taking this next step toward fairer distribution of tax revenue remains elusive.

For businesses within St. Louis County where taxing rules, structures and measurement of the tax object are uniform, differentials in local property tax rates remain a factor in evaluating where to locate or expand a business facility. Active tax competition and disparities in tax revenue among taxing jurisdictions in St. Louis County help to make some business locations more desirable than others. Taxing jurisdictions within St. Louis

/static/5a0c602bf43b5594845abb81/t/5ee79779c63e0b7d057437f8/1592235907012/ICRICT+Glob al+pandemic+and+international+taxation.pdf [https://perma.cc/CV82-LRSE].

${ }^{90} \mathrm{Cf}$. supra note 66 and accompanying text (constitutional rights to travel and reside within the national borders but not across).

${ }^{91}$ Subject to possible use tax collection obligations. See Wayfair, 138 S. Ct. 2080. 
County have not unified to distribute revenue to promote development for the entire region, but that step would be administratively feasible because the infrastructure for it is already in place. Only rates of tax and the distribution formula would require revision to make fairer shares of resources available to all districts.

If distribution of tax revenue to achieve greater uniformity in governmental services is a desirable goal, as this Article argues it is, uniform tax rules, uniform tax rates, and a distribution formula meeting community needs is critical to achieve that goal. Disparities in revenue distribution in St. Louis County are easy to level with the fundamental tax base uniformity already in place, even though leveling is not occurring or even under discussion. Globally, the OECD is promoting increased uniformity, not to level tax resource distribution, but to combat tax competition that diminishes tax revenue for developed economies. While frequently couched in terms of MNEs and other taxpayers ceasing to engage in tax avoidance and paying their "fair share" of tax, a primarily political objective, ${ }^{92}$ generating increased tax revenue to ameliorate relative poverty locally has not been matched with worldwide tax revenue distribution to eliminate absolute poverty internationally. ${ }^{93}$

If assistance and cooperation from less developed economies in combating tax competition and tax avoidance is necessary to advance the developed economies' efforts, fairer worldwide tax revenue distribution is critical, and less developed economies must be given a reason not to use their tax systems to compete. Globally, distribution is of first importance but uniformity remains a close second in significance because without uniformity, as is present in the St. Louis County administered property value tax base, it is difficult to compare tax levies to ascertain whether one country is collecting an appropriate tax on its share of the worldwide tax base. The tax base in international projects is income, but not all tax systems measure income in an identical manner. The next section considers whether international projects facilitate any movement toward uniform rules to facilitate fairer tax revenue distribution. No international project has selected tax revenue distribution, as opposed to tax base distribution, as its objective except as an incidental effect of tax base allocation.

IV. INTERNATIONAL TAX COMPETITION AND REALLOCATING THE TAX BASE

\section{A. BEPS and Other Projects}

In response to aggressive tax planning and "harmful" tax competition, ${ }^{94}$ various proposals have been crafted to prevent base erosion and profit shifting. These proposals are particularly salient in light of the increasing digitalization of the economy and a surge in intangible digital assets. As the current leader in international tax, the OECD has spearheaded most projects, such as the Base Erosion and Profit Shifting (BEPS) action

92 See Brassey \& Ordower, supra note 37, at 99 (“[P] inequality within national borders is really a political demand to further the economic interests of particular groups that are already among the most economically privileged when viewed on an international spectrum.").

${ }^{93}$ See Id. (finding that political will to confront international poverty is lacking); infra Part IV.

${ }^{94}$ Speculative costs of revenue loss show that profit shifting has a more harmful effect on developing countries, with the implied long run revenue loss for advanced economies totaling $0.6 \%$ of the GDP and close to $2 \%$ of the GDP for developing countries. Ernesto Crivelli, et al., Base Erosion, Profit Shifting and Developing Countries 20 (IMF, Working Paper No. 15/118, 2015), https://www.imf.org/external/pubs/ft/wp/2015/wp15118.pdf [https://perma.cc/RK4F-A5UZ]. 
reports and the Global Anti-Base Erosion (GloBE) proposal. In parallel with the OECD projects, the EU also has relaunched the $\mathrm{CCCTB}^{95}$ to harmonize the taxing rules and standards of member states and to better incorporate the BEPS actions through cohesive legislation. The CCCTB more simply tries to apportion the corporate income tax base consistently and predictably among the EU jurisdictions in which the company operates so that each may tax its share of an MNE's income under its own income tax rules but with no part of the income subject to tax in more than one jurisdiction or not subject to tax in any jurisdiction. ${ }^{96}$ While the CCCTB project does not seek complete uniformity in computational rules for tax purposes beyond what is necessary to facilitate apportionment, its adoption should result in considerable convergence of tax rules to create a consistent base to apportion.

Requested and endorsed by the G2097 leaders, the OECD aggregated 15 Actions intended to combat the abuse of profit shifting as exacerbated by the digital economy. The Actions confront the unique challenges of the digital economy; ${ }^{98}$ aim to neutralize hybrid mismatch arrangements; ${ }^{99}$ strengthen CFC rules; ${ }^{100}$ reduce base erosion via interest deductions and other financial payments; ${ }^{101}$ recognize and counter harmful tax practices; ${ }^{102}$ prevent treaty abuse; ${ }^{103}$ prevent the artificial avoidance of permanent establishment; ${ }^{104}$ ensure transfer pricing outcomes are in line with value creation; ${ }^{105}$ collect and analyze data on BEPS; ${ }^{106}$ require the disclosure of aggressive tax planning arrangements; ${ }^{107}$ re-examine

${ }^{95}$ Q\&A CCCTB, supra note 18.

${ }^{96}$ Income not subject to taxation in any jurisdiction is known as "stateless income." See Edward D. Kleinbard, Stateless Income, 11 FLA. TAX REV. 699, 702-07 (2011).

${ }^{97}$ The Group of 20 is organization of finance ministers and central bank governors, and member countries account for $80 \%$ of the world's GDP. G20 aims to unite world leaders on economic, political, and health challenges. See Michael Crowley, What Is the G20?, N.Y. TIMES (June 27, 2019), https://www.nytimes.com/2019/06/27/world/asia/what-is-the-g20.html [https:// perma.cc/WVN8-FBUR].

98 OECD/G20 Base Erosion and Profit Shifting Project, OECD, Addressing the Tax Challenges of the Digital Economy, Action 1 - 2015 Final Report (2015) [hereinafter Action $1]$.

${ }^{99}$ OECD/G20 Base Erosion and Profit Shifting Project, OECD, Neutralising the EFFeCts of Hybrid Mismatch ARRAngements, ACtion 2 - 2015 Final RePORT (2015). $C f$. I.R.C. $\S$ 267A (denying deductions or exclusions for related party and hybrid transactions resulting in a mismatch of inclusion and exclusion or deduction).

100 OECD/G20 Base Erosion and Profit Shifting Project, OECD, Designing EfFective Controlled Foreign COMPANy Rules, ACtion 3 - 2015 Final RePort (2015).

101 OeCD/G20 Base Erosion and Profit Shifting Project, OECD, Limiting Base Erosion Involving Interest Deductions and Other Financial Payments, Action 4 - 2015 FINAL REPORT (2015).

102 OECD/G20 Base Erosion and Profit Shifting Project, OECD, Countering Harmful tax Practices More Effectively, Taking into Account Transparency and SUBSTANCE, ACTION 5 - 2015 FinAl REPORT (2015).

103 OECD/G20 Base Erosion and Profit Shifting Project, OECD, Preventing the Granting of Treaty BenEFits in InAPPROPRiate Circumstances, ACtion 6 - 2015 FinAl RePORT (2015).

104 OeCd/G20 Base Erosion and Profit Shifting Project, OeCD, Preventing the Artificial Avoidance of Permanent Establishment Status, Action 7 - 2015 Final Report (2015).

105 OECD/G20 Base Erosion and Profit Shifting Project, OECD, Aligning Transfer Pricing Outcomes with Value Creation, Action 8-10 - 2015 Final Reports (2015).

106 OECD/G20 Base Erosion and Profit Shifting Project, OECD, Measuring and MONITORING BEPS, ACTION 11 - 2015 FINAL REPORT (2015).

107 OECD/G20 Base Erosion and Profit Shifting Project, OECD, Mandatory Disclosure Rules, ACTION 12 - 2015 FinAl REPORT (2015). 
transfer pricing; ${ }^{108}$ improve dispute resolution mechanisms; ${ }^{109}$ and create a multilateral instrument for synchronized modification of bilateral tax treaties that incorporates the OECD Actions without renegotiating existing bilateral treaties. ${ }^{110}$ Only four of the actions, however, were agreed upon as part of the minimum standards discussed in the BEPS Inclusive Framework and committed to by the member countries. ${ }^{111}$

Despite such ambitious and all-encompassing objectives, the action plans have fallen short of some critics' expectations. ${ }^{112}$ A repeated criticism of the BEPS project is that it does not address the underlying faults of the existing international tax system and instead rehashes and strengthens existing rules and principles. ${ }^{113}$ Some commentators state that the foundational tax base allocation rules that pre-exist and are enforced by BEPS ensure that higher income countries are consistently assigned a greater share of revenue than lower income countries. ${ }^{114}$ The OECD has recognized and committed itself to being

108 OECD/G20 Base Erosion and Profit Shifting Project, OECD, Transfer Pricing Documentation And COUnTRY-By-COUntry Reporting, ACtion 13 - 2015 Final Report (2015) [hereinafter ACTION 13].

109 OECD/G20 Base Erosion and Profit Shifting Project, OECD, Making Dispute Resolution Mechanisms More Effective, Action 14 - 2015 Final Report (2015).

110 OECD/G20 Base Erosion and Profit Shifting Project, OECD, Developing a Multilateral Instrument to Modify Bilateral Tax Treaties, Action 15 - 2015 Final Report (2015) [hereinafter ACTION 15].

111 The minimum standards which have been committed to are: fighting harmful tax practices (Action 5), preventing tax treaty abuse (Action 6), improving transparency with Countryby-Country reporting (Action 13), and enhancing the effectiveness of mechanisms for dispute resolution (Action 14). OECD, InCLuSIVE Framework on BEPS: Progress RePORT July 2016JUNE 2017 9-12 (2017). To date, 139 countries are members of the OECD/G20 Inclusive Framework on BEPS. Members of the OECD/G20 Inclusive Framework on BEPS, OECD, https://www.oecd.org/tax/beps/inclusive-framework-on-beps-composition.pdf [https://perma.cc /UX73-8CHR] (last updated Feb. 2021) [hereinafter BEPS Members].

112 See Adam H. Rosenzweig, Defining a Country's "Fair Share" of Taxes, 42 Fla. St. U. L. REV. 373 (2015). For conceptual background on developing international fair taxation standards, see Steven A. Dean, Neither Rules nor Standards, 87 Notre Dame L. ReV. 538 (2011); Nancy H. Kaufman, Fairness and the Taxation of International Income, 29 L. \& POL'Y INT'L Bus. 145 (1998).

${ }^{113}$ Reuven S. Avi-Yonah \& Haiyan Xu, Evaluating BEPS: A Reconsideration of the Benefits Principle and Proposal for UN Oversight, 60 HARV. BuS. L. REV.186, 208 (2016). See also Mindy Herzfeld, The Case Against BEPS: Lessons for Tax Coordination, 21 FLA. TAx REV. 1 (2017) (project's lack of coordinated rules results in vague standards that everyone accords different meanings within each country. Further, the OECD missed the opportunity to truly examine the underlying causes of the issues and meaningfully discuss the reasons for tax competition and the tension between emerging economies and OECD members); Michael P. Devereux \& John Vella, Are We Heading Towards a Corporate System Fit for the 21st Century?, 35 FisCAL STUD. 449 (2014) (it is not a fundamental reform because the OECD does not set out to change the framework or even question the desirability or logic of the existing regime); Jakib A. Bartoszewski \& Andew P. Morriss, An Archipelago of Contrasts: Blacklists, Caribbean Autonomy and the New Tax Colonialism, IFC (June 17, 2020), https://www.ifcreview.com/articles/2020/june/an-archipelago-of-contrastsblacklists-caribbean-autonomy-and-the-new-tax-colonialism [https://perma.cc/BTL6-3EE3] (arguing that the blacklisting of Caribbean tax havens by the EU is a new form of colonialism and the EU should instead focus on designing its own efficient tax regime to protect its tax revenue); Steven A. Dean, FATCA, the U.S. Congressional Black Caucus, and the OECD Blacklist, 99 TAX NOTES INT'L 83 (July 6, 2020) (discussing the role of the Congressional Black Caucus in the U.S. withdrawal from the OECD project on harmful tax competition because of its adverse effect on low wealth, predominantly black jurisdictions).

${ }^{114}$ Christians \& van Apeldoorn, supra note 32, at 2. 
more inclusive of developing countries, ${ }^{115}$ although some believe that the only way to achieve this is by overhauling the foundational principles of the existing system, which inherently favors higher income countries, and which BEPS fails to do. ${ }^{116}$ Others believe that the Actions may allow for greater source-country taxation, which could be beneficial for developing countries that generally are considered source countries, provided that the necessary multinational consensus on the allocation of taxing rights is forthcoming. ${ }^{117}$

Action 13 re-examines transfer pricing documentation and requires country-bycountry reporting. The Action includes the requirement that MNEs provide relevant governments with the information necessary to correct and fair allocation of income among states, ${ }^{118}$ while Action 15 contemplates developing a multilateral instrument to synchronize modification of existing bilateral treaties without the need to renegotiate those treaties. ${ }^{119}$ Some consider the country-by-country reporting recommendation innovative and collaborative, as it enhances transparency and allows informed discussion. ${ }^{120}$ The multilateral instrument proposal has been described as almost revolutionary given the current predominantly bilateral tax treaty regimes, and some have argued that success of this proposal would be sufficient to qualify the BEPS project as a success, regardless of the success or failure of the other actions. ${ }^{121}$

B. GloBE - Minimum Tax and Base Erosion

Following concern and criticism that the BEPS final Actions do not go far enough in addressing the issues of profit shifting, the OECD responded with the GloBE proposal. Pillar one of GloBE concerns the allocation of tax rights among jurisdictions, and Pillar Two imposes two new taxes: a global minimum tax on corporate profits and a tax on base eroding payments. ${ }^{122}$ Encompassed within the global minimum tax is an income inclusion rule, implementing a supplementary tax on the income of foreign entities where the income otherwise would be subject to a tax below the effective minimum rate. The minimum tax also would allow residence jurisdictions to switch from an exemption to a credit method when profits attributable to a permanent establishment are subject to an effective rate below the minimum rate. ${ }^{123}$ Functionally, the minimum tax would resemble the existing U.S. worldwide taxation system under which U.S. persons are taxable on their worldwide

115 OeCD, Public Consultation Document: Secretariat Proposal for a "Unified APPROACH" UNDER PILlAR ONE 6 (2019), https://www.oecd.org/tax/beps/public-consultationdocument-secretariat-proposal-unified-approach-pillar-one.pdf [https://perma.cc/5DKW-6ELY].

${ }^{116}$ See Herzfeld, supra note 113.

${ }^{117}$ David Spencer, BEPS and Allocation of Taxing Rights, 29 J. INT'L TAX'N 143, 155 (2018).

118 See Action 13, supra note 108, at 23.

119 See ACTiOn 15, supra note 110.

120 Yariv Brauner, What the BEPS? 16 FLA. TAx REV. 55, 104-05 (2014). But see Devereux \& Vella, supra note 113, at 461-62 (noting that the information is only to be disclosed to tax authorities and not the public, therefore reducing its transparency).

${ }^{121}$ Brauner, supra note 120, at 107. See also Rasmus Corlin Christensen \& Martin Hearson, The New Politics of Global Tax Governance: Taking Stock a Decade After the Financial Crisis, 26 REV. INT'L POL. ECON. 1068, 1077 (2019) (noting that the multilateral instrument is the result of deeper and broader sovereignty-constraining effects than ever before).

122 See OECD/G20 Inclusive Framework on BEPS, OECD, Programme of Work to Develop a Consensus Solution to the Tax Challenges Arising From the Digitalisation of THE ECONOMY (2019) [hereinafter OECD/G20 INCLUSIVE FRAMEWORK ON BEPS].

123 OecD, Public Consultation Document Global anti-Base Erosion Proposal (GloBE) (Pillar Two): Tax Challenges Arising from the Digitalization of the Economy 6 (2019) [hereinafter GloBE Pillar Two Public Consultation]. 
income in the U.S. ${ }^{124}$ but the U.S. tax is reduced through a tax credit by the tax properly payable to the source jurisdiction. ${ }^{125}$

The GloBE tax on base eroding payments includes an undertaxed payments rule. That rule denies a deduction or imposes a tax at the payment's source if the payment is to a party related to the payer and the payment is not subject to the specified minimum tax rate where it is received. This aspect of the GloBE tax proposal operates similarly to the base erosion anti-avoidance minimum tax the U.S. enacted in $2017 .{ }^{126}$ In addition, the GloBE tax more generally denies treaty benefits such as a reduced withholding rate if a payment does not result in income that is subject to tax at the specified minimum tax rate. ${ }^{127}$

The GloBE project suggests a means to remove tax from the international mix of business development incentives. Although GloBE focuses on the digital economy, its principles apply to a broader range of problems as well. GloBE's two fundamental principles resemble approaches the U.S. and other jurisdictions already have taken with respect to their own resident MNEs. One principle includes the income of foreign branches and controlled entities in the income of the parent or principal entity based in the higher tax jurisdiction if the branch or controlled entity is resident in a low tax jurisdiction. ${ }^{128}$ Unlike most countries that have territorial income tax systems under which branch income is only taxable where earned, the U.S. already includes the income of foreign branches under the rubric of worldwide taxation of its citizens, residents and domestic entities. Unless the U.S. taxpayers interpose a foreign corporation, ${ }^{129}$ they are taxable on foreign source income immediately and capture no benefit from operating or investing directly in a low tax jurisdiction. ${ }^{130}$

The GloBE proposal as applied to controlled entities resembles existing $\mathrm{CFC}^{131}$ regimes common to the U.S. and other jurisdictions. ${ }^{132}$ In the U.S., Subpart F income ${ }^{133}$ of a CFC is taxable to its U.S. shareholders. ${ }^{134}$ Like the GloBE minimum tax treatment of

${ }^{124}$ See I.R.C. § 61; Treas. Reg. § 1.1-1(b).

${ }^{125} \mathrm{See}$ I.R.C. $\S 901(\mathrm{~b})(1)$.

126 See I.R.C. § 59A.

${ }^{127}$ GlobE Pillar Two Public Consultation, supra note 123, at 34.

128 See id. at 29-30.; Devereux ET AL., supra note 16, at 1-2; Ruth Mason, The Transformation of International Tax, 114 AM. J. INT'L L. 353, 376 (2020).

129 The U.S. may not tax a foreign corporation on its income from non-U.S. sources and not effectively connected with the conduct of a U.S. trade or business directly. I.R.C. $\S \S 11(d), 882$ (tax on foreign corporations). The controlled foreign corporation anti-avoidance rules discussed infra note 132 and accompanying text may tax all or part of the foreign corporation's income to its U.S. shareholders.

${ }^{130}$ New but limited territoriality in U.S. tax law under section $245 \mathrm{~A}$, added by the TCJA, now provides a 100 percent dividends received deduction for distributions from foreign corporations to U.S. corporate shareholders owning at least 10 percent of the foreign corporation enables U.S. corporations to operate outside the U.S. through non-U.S. subsidiaries and, subject to CFC and base erosion minimum tax limitations, avoid the U.S. income tax.

${ }^{131}$ A CFC is a foreign corporation in which United States shareholders (U.S. shareholders) own more than 50 percent of the voting shares and share value. I.R.C. $§ 957(a)$. Section 951(b) defines a U.S. shareholder as a U.S. person owning, directly or indirectly, 10 percent or more of the voting shares or the share value of the foreign corporation. I.R.C. $\$ 951(b)$.

132 See Sebastian Dueñas, CFC Rules Around the World, TAX Found. (June 2019), https://files.taxfoundation.org/20190617100144/CFC-Rules-Around-the-World-FF-659.pdf [https:// perma.cc/ZX9A-3V26] (describing CFC rules outside the U.S.).

${ }^{133}$ I.R.C. $\S 952$.

${ }^{134}$ Section 951(a) includes the U.S. shareholder's pro rata share of the CFC's Subpart F income, as defined in section 952, in the shareholder's U.S. income subject to tax currently without distribution from the CFC. I.R.C. $\S \S 951(a), 952$. 
rates at least equal to the minimum tax rate, ${ }^{135}$ if the foreign base company income ${ }^{136}$ portion of the subpart $\mathrm{F}$ income is taxed in the $\mathrm{CFC}$ residence country at a rate greater than 90 percent of the U.S. corporate tax rate, that portion of the subpart $\mathrm{F}$ income is not subject to CFC inclusion in the U.S. shareholders' incomes. ${ }^{137}$ Foreign base company income includes income from sales and services attributable to the CFC if there is little or no business reason, other than tax, for sourcing the income in that corporation. ${ }^{138}$ U.S. noncorporate shareholders of CFCs also must include their pro rata shares of the CFC's global intangible low-taxed income (GILTI) annually, ${ }^{139}$ but corporate shareholders of CFCs include only half their shares of the GILTI income because they may deduct half the GILTI income under the foreign derived intangible income provision. ${ }^{140}$ GILTI includes income produced by intangible assets, including income from the digital economy, which is GloBE's focus, in U.S. shareholders' portions of includable CFC income. ${ }^{141}$ For instance, intellectual property produces digital economy income that is predominantly intangible and which becomes part of net tested CFC income ${ }^{142}$ but generates no offsetting net deemed tangible income return ${ }^{143}$ because intangible intellectual property is excluded from qualified business asset investment. ${ }^{144}$

The second pillar of the GloBE proposals, the "base erosion" proposal, disallows deductions and treaty benefits for base erosion payments. A base erosion payment but for the GloBE proposal rule would yield a deduction or enjoy a treaty benefit without the payment becoming subject to tax in the recipient's jurisdiction at or above a designated minimum rate. Tax rate arbitrage with related party payments is commonplace where no anti-avoidance rule or minimum tax discourages it. Where the parties to the transaction have a community of economic interests as related parties do or have some other opportunity to return part of the low tax jurisdiction's profit to other party free from a tax in the higher tax jurisdiction, the parties may share the tax savings from the structure without any non-tax economic cost to either party. ${ }^{145}$ The base erosion proposal addresses this longstanding problem of tax rate arbitrage. Where the payments are between related parties, transfer pricing limitations have long enabled the tax administrator to attribute the income to a different taxpayer than the taxpayer receiving it. ${ }^{146}$ The base erosion proposal supplements the inquiry into whether the payment to a related party is an arms' length transfer price by limiting the tax arbitrage opportunity for all related party payments. The U.S. recently sought to accomplish a similar tax arbitrage limiting function with its separate base erosion minimum tax, known as BEAT, for certain related party payments. ${ }^{147}$

The minimum tax and the denial of the deduction or treaty benefit would compel the low tax jurisdiction to enact a rate at least equal to the minimum rate. Failing to collect

${ }^{135}$ GloBE Pillar Two Public Consultation, supra note 123.

${ }^{136}$ I.R.C. $\S 954$.

${ }^{137}$ I.R.C. $\S 954(\mathrm{~b})(4)$.

138 I.R.C. $\$ 954(\mathrm{~d})$.

139 See I.R.C. $\S 951$ A (added by the TCJA).

${ }^{140}$ I.R.C. $\S 250$ (added by the TCJA).

${ }^{141}$ I.R.C. $\$ 951(\mathrm{a})$.

${ }^{142}$ I.R.C. $\S 951 \mathrm{~A}(\mathrm{c})$.

${ }^{143}$ I.R.C. $\S 951 \mathrm{~A}(\mathrm{~b})(2)$.

${ }^{144}$ I.R.C. $\S 951 \mathrm{~A}(\mathrm{~d})$.

${ }^{145} C f$. I.R.C. $\$ 7701$ (o) (requiring economic substance independent of tax benefits for an arrangement to yield the tax outcomes that the parties have structured into the transaction).

${ }^{146}$ I.R.C. $\S 482$ and related regulations.

${ }^{147}$ I.R.C. $\S 59$ A (added by the TCJA, imposing a minimum tax at 10 percent, increasing to 12.5 percent in 2025). 
the minimum tax amount would relinquish the potential tax revenue without having a benefit to offer to the investor because the high tax jurisdiction will capture the difference between the low tax jurisdiction's actual tax and the minimum tax or all the revenue in the case of the base erosion payment. ${ }^{148}$ Although the BEPS projects, when fully implemented, may represent a principle of full taxation, ${ }^{149}$ the policy consensus of the BEPS project has been that no or low taxation is not itself a cause of concern. ${ }^{150}$ BEPS' objectives are: (1) to prevent profit shifting by supplementing traditional transfer pricing controls with a minimum tax, and (2) to reduce tax competition by segregating transactions with related parties even if at an arms' length price whenever they do not incur a tax equal to or greater than the minimum tax. The latter objective may be more difficult to achieve insofar as it burdens a discrete class of taxable income from transactions between related persons that is taxed less favorably than other income even though it may flow from arms' length transactions that transfer pricing law would accept as correctly characterized and would not reallocate between or among taxpayers. Critics consider the application of the deduction denial and loss of treaty benefit to even arms' length payments between related parties as adversely affecting countries' ability to attract investment and activity that does not abuse tax rules because a country chooses to attract investment with low or zero tax rates. The deduction denial and loss of the treaty benefit rule prevents countries from taxing profits generated through actual activity taking place within their borders at any rate they choose. That tax rate limitation diminishes the sovereignty of low and zero tax countries. ${ }^{151}$ Other commentators appreciate that the minimum tax could significantly reduce the distortions of international capital allocation and remove incentives to shift profits, although it does not fully equalize the tax burden of domestic and foreign investment. ${ }^{152}$ Similarly, commentators express the view that a minimum tax infringes on sovereignty is a questionable premise, as unfettered sovereignty can only be claimed in purely internal situations. In the international context, external interests may require compromise of sovereignty to maintain peaceful relations and cross-border commerce. ${ }^{153}$

The GloBE proposal does acknowledge that there is international capital imbalance disfavoring less developed economies. The OECD views the GloBE proposal as a way to remedy that imbalance. The proposal would allocate a somewhat greater share of the base to less developed jurisdictions. Under the guise of tax fairness, the minimum tax will inhibit jurisdictions from engaging in tax-based competition for inbound investment with tax concessions for international investors. Less developed jurisdictions will collect more tax on their larger shares of the tax base than they might have collected with robust tax competition because they will impose a tax at a rate no less than the minimum tax.

Like the other OECD projects, the GloBE project is mindful of tax sovereignty but, nevertheless, intrudes upon taxing sovereignty with effective economic compulsion to enact a minimum rate of tax through the VAT directive that limits the tax sovereignty of the EU member states. ${ }^{154}$ GloBE provides a trade-off for the relinquishment of tax

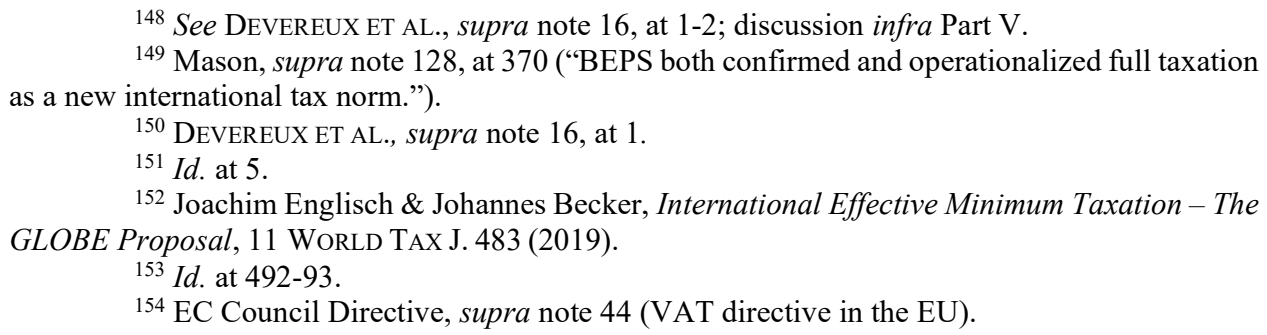


sovereignty by restructuring the allocation of the income tax base such that more allocation is accorded to less developed countries. Except for the minimum rate, the project does not promote broad taxing uniformity. Neither does the project recommend uniform rules of taxation across jurisdictions. It leaves the administration and collection of tax on the jurisdiction's share of the tax base to each taxing jurisdiction. Accordingly, a jurisdiction interested in offering a tax-based subsidy might adjust its tax rules to benefit the subsidized taxpayer while maintaining a nominal tax rate equal to the minimum. The complexity of addressing all possible tax subsidization permutations will be challenging to police. Despite the BEPS' objective to prevent erosion of the base with international coordination, developed and dominant economies exercising tax sovereignty, even consistent with BEPS, have flexibility in designing their own domestic tax rules in a manner that might impose some of their rules indirectly on other economies. By applying its own taxing rules in determining whether or not an MNE was subject to tax at a rate equal to or greater than the minimum tax rate, a developed and dominant economy might compel other economies to coordinate their tax rules. Results would differ depending on the rules in the taxpayer's home jurisdiction as opposed to another major economy's rules. Where the MNE is operating in multiple jurisdictions and each or many jurisdictions apply their own taxing rules to determine whether the MNE is paying the minimum tax amount, a cacophony of outcomes might result offering little improvement over what exists now.

Ultimately, it seems that the success of the GloBE proposal depends on the nearunanimous adoption of the minimum tax and the tax on base eroding payments. Otherwise, the proposal might exacerbate tax competition problems, as non-adopting countries that refrain from implementing the measures could manipulate this to their tax advantage. They might entice MNEs to move their parent company to their jurisdiction by offering a tax home free from the minimum tax requirement. Countries adopting the minimum tax and base eroding tax must design methods to prevent migration of MNEs as the U.S. sought to do with its anti-inversion legislation. ${ }^{155}$ Similarly, harmonization of the tax base and applicable thresholds is essential to the success of the project lest countries simply continue to compete by adjusting rules of inclusion and thresholds.

\section{Tax Competition, Avoidance, and Evasion}

While the OECD pushes on with its project to overhaul taxation of MNEs and has 140 countries scheduled to participate in meetings on a revised international tax framework, ${ }^{156}$ the framework is unlikely to eliminate international tax competition. Even among the 140 participants, a variety of competing concerns may manifest themselves among the participants. The U.S., for example, continues to express reservations with

155 I.R.C. $\$ 7874$.

${ }^{156}$ Stephanie Soong Johnston, OECD Postpones Key Meeting of Global Tax Overhaul Project, TAX Notes TODAy InT'L (May 5, 2020), https://www.taxnotes.com/featured-news/oecdpostpones-key-meeting-global-tax-overhaul-project/2020/05/04/2ch38 [https://perma.cc/76WNAFWC]. 
respect to digital services, ${ }^{157}$ and 53 U.N. member states ${ }^{158}$ are not even included in the OECD deliberations. Moreover, while the base erosion projects address a variety of methods that taxpayers use to shift income source to low tax jurisdictions, they do not unify all computational rules and tax rates.

The OECD also publicly identified tax havens that engaged in harmful tax competition to shame or coerce them to cooperate with the major market jurisdictions and share information. Information sharing would assist the developed economy countries to identify investors subject to their general taxing jurisdiction when those investors conceal assets in low tax jurisdictions to avoid home country taxes. ${ }^{159}$ The harmful tax competition project has encouraged rapid growth of agreements on information sharing. ${ }^{160}$ The U.S. also coerced international cooperation by enacting legislation denying favorable U.S. tax status to foreign entities that did not provide information on their U.S. direct and indirect investors who were investing outside the U.S. and not reporting their income from those investments. ${ }^{161}$ Perhaps the most interesting action regarding information gathering was when Germany purchased a stolen list of German investors in Liechtenstein Stiftungen to discover those investors' evasion of German tax liability. ${ }^{162}$

The U.S. approach to tax competition differs somewhat from that of other OECD countries. Since the U.S. taxes its citizens, residents, and domestic entities on their income from all sources worldwide, ${ }^{163}$ operating or investing directly in low tax jurisdictions provides U.S. persons no tax benefit provided that the U.S. taxpayer reports completely and honestly. Hiding assets and failing to report offshore income is tax fraud which may subject the taxpayer to civil and criminal penalties. ${ }^{164}$ The tax on worldwide income in the U.S. similarly eliminates the benefit of negotiated tax concessions insofar as the U.S. applies a credit rather than exemption ${ }^{165}$ to all foreign source income and generally cedes primary taxing authority to the source country through the foreign tax credit ${ }^{166}$ but

157 See id.; William Hoke, U.S. Says OECD Talks on Digital Economy Have Hit an Impasse, TAX NOTES (June 22, 2020), https://www.taxnotes.com/tax-notes-federal/digital-economy /us-says-oecd-talks-digital-economy-have-hit-impasse/2020/06/22/2cmvw [https://perma.cc/8ZNZX3CF]; Stephanie Soong Johnston, Business Groups Rally Around OECD Global Tax Deal Work, TAX Notes TODAY InT'L (June 29, 2020), https://www.taxnotes.com/tax-notes-today-international /digital-economy/business-groups-rally-around-oecd-global-tax-deal-work/2020/06/29/2cnr7

[https://perma.cc/Z657-3LQD]; Stephanie Soong Johnston, Global Tax Revamp Talks 'Not on Life

Support,' Saint-Amans Says, 98 TAX NoteS INT'L 1536 (June 29, 2020), https://www.taxnotes.com/tax-notes-international/politics-taxation/global-tax-revamp-talks-notlife-support-saint-amans-says/2020/06/29/2cnj3 [https://perma.cc/Z4Y3-HPTP].

158 The U.N. has 193 member states, and 140 member states participate, leaving 53 nonparticipants. See About the UN, UN, https://www.un.org/en/about-un/index.html [https://perma.cc /Q56A-TSKD] (193 U.N. member states); Johnston, supra note 156 (about 140 U.N. member states participate in OECD deliberations).

${ }^{159}$ See OECD HARMFUl TAX COMPETITION, supra note 12 , at 24, 50.

160 TIEA, supra note 9 (showing increasing numbers of agreements from 2001 to 2012).

${ }^{161}$ See Foreign Account Tax Compliance Act (FATCA).

162 Ordower, supra note 42, at 124.

${ }^{163}$ I.R.C. $\$ 61$ (gross income includes all income from whatever source derived); Treas.

Reg. § 1.1-1(b) (worldwide income taxed).

${ }^{164}$ I.R.C. $\S 7201$.

${ }^{165}$ Cf. GloBE Pillar Two Public Consultation, supra note 123 and accompanying text (the exclusion to credit shift under Pillar II of the OECD GloBE Proposal).

${ }^{166}$ I.R.C. $\S 901$. 
continues to claim the difference between the U.S. tax on the income and the tax imposed by the source jurisdiction. ${ }^{167}$

U.S. taxpayers may avoid a current tax in the U.S. by operating or investing outside the U.S. through a tax opaque, non-U.S. entity. ${ }^{168}$ The U.S., however, has enacted an array of mechanisms to protect its claim to a share of the foreign source income in which U.S. persons have an indirect interest through a non-U.S. corporation, including the CFC, ${ }^{169}$ passive foreign investment company (PFIC), ${ }^{170}$ expatriated entity, ${ }^{171}$ and now repealed foreign personal holding company ${ }^{172}$ provisions. The CFC provisions even permit the U.S. to reach across national borders to tax part of the income of CFCs to their U.S. shareholders without any actual or constructive distribution from the CFCs to the U.S. shareholders as a necessary requirement for the tax imposition. With respect to the hidden investment capital of U.S. persons, the U.S. has also sought to enlist the assistance of non-U.S. financial institutions in its quest to tax the income that capital generates. ${ }^{173}$

D. Tax Base Allocation and Apportionment

Underlying any allocation or apportionment of an income tax base is an implicit assumption that a base exists to allocate and apportion. While definitions of income for tax purposes exist, ${ }^{174}$ the elements of any income tax base enjoy commonalities with all income tax bases, but the details of inclusion, exclusion, and deduction differ across

${ }^{167}$ I.R.C. $\S 904$. For example, A invests in country X and earns $\$ 100$. Country X imposes a $\$ 10$ tax on A's income in X. The U.S. would impose a $\$ 30$ tax on the $\$ 100$ income from $X$ but allows $\mathrm{A}$ a tax credit of $\$ 10$ (the $\mathrm{X}$ tax) and imposes a net tax on the $\mathrm{X}$ source income of $\$ 20$. If the $X$ tax were $\$ 40$, the U.S. tax credit for A would be limited to $\$ 30$, the amount of the U.S. tax on the income.

${ }^{168}$ Tax opacity is characteristic of corporations under subchapter C of the I.R.C. and contrasts with tax transparency of partnerships and other entities under subchapter K of the I.R.C. A tax opaque entity is itself subject to the income tax while a tax transparent entity is not but its owners are taxable on their proportional shares of the entity's income, as if the owners received the income from the source and in the manner that the entity received it. I.R.C. $\S 702$ (b). Non-U.S. business entities that are included in the foreign entities list in Treasury regulation section $301.7701-2(b)(8)$ are tax opaque, and the default classification of other foreign entities in which the entity's owners have limited liability is also tax opaque, but the owners of the latter group may elect tax transparency. Treas. Reg. § 301.7701-3(b)(2) (referred to as the check-the-box regulation). Both domestic and foreign tax transparent entities may elect to be tax opaque. Treas. Reg. $\S 301.7701-3(\mathrm{a})$. There also are various hybrid entities such as regulated investment companies that are tax opaque entities but are allowed a deduction for distributions to their shareholders so that they do not pay tax at entity level. I.R.C. $\$ 852$.

${ }^{169}$ See I.R.C. $\S 951$ (U.S. persons owning 10 percent or more of the shares of a CFC include their shares of Subpart F and GILTI income).

${ }^{170}$ See I.R.C. $\$ 1291$ (income recognition in respect of stock in PFICs). See also I.R.C. $\S \S$ 1293, 1296 (current inclusion of PFIC income election and mark to market election).

${ }^{171}$ I.R.C. $\S 7874$ (tax on inverted entities).

172 I.R.C. $§ 551$ (repealed 2004).

${ }^{173}$ Under FATCA, non-cooperating foreign financial institutions lose the benefit of withholding reductions on U.S. investments. See I.R.C. § 1471.

${ }^{174}$ For example, an oft-cited definition for a comprehensive income tax base is the SchanzHaig-Simons' definition where income is the algebraic sum of consumption plus or minus the change in the taxpayer's net worth from the beginning to the end of the tax measuring period. HENRY Simons, Personal Income Taxation: the Definition of Income as a Problem of Fiscal Policy 49 (1938). Only rarely, however, do jurisdictions include unrealized appreciation and depreciation of property in their tax bases. The U.S. does not include unrealized appreciation and depreciation generally but does include both for certain financial positions under I.R.C. section 1256, dealer-held securities under I.R.C. section 483 and all property of expatriating taxpayers under I.R.C. section 877A. 
jurisdictions. For example, most U.S. states that impose an income tax use federal adjusted gross income ${ }^{175}$ as their point of departure for determining the base for the tax. ${ }^{176}$ Nevertheless, state income tax rules are not uniform. Each state modifies the amount of adjusted gross income to arrive at the income base upon which it imposes its income tax. ${ }^{177}$

Internationally, the components of income tax bases vary. While the U.S. includes gains from the sale or exchange of property in the income tax base, ${ }^{178}$ Germany does not tax gain on tangible personal property held more than a year or real property held more than ten years. ${ }^{179}$ Thus, a U.S. citizen who is resident in Germany and sells property in Germany might have no inclusion of gain from the sale of property in Germany but have the gain included in their U.S. income for tax purposes without there being any difference in the taxpayer's economic income in Germany and the U.S. Certainly, tax systems have tended to copy elements from other tax systems, ${ }^{180}$ and tax rules have converged considerably over the years so that computational differences between jurisdictions may be smaller today than in earlier decades. ${ }^{181}$ Yet differences endure and a single common definition of taxable income remains elusive. Since BEPS seeks to eliminate profit shifting and base erosion, consistent definitions of profit and base are essential to pursue those goals. Definitional disparities undermine the potential success of the OECD projects because parties to any international agreements may be agreeing to a methodology but not to the tax items to which it applies. The definitional disparities leave open the possibility that even if an OECD project succeeds in gaining international consensus, its success in application may remain incomplete.

Turning to the EU, in the hope of strengthening the single market, the updated CCCTB proposal ${ }^{182}$ aims to build upon the BEPS actions and effectively integrate the reforms by harmonizing the approach of member states. ${ }^{183}$ This would be achieved through a two-step plan: first, the proposal calls for the implementation of a Common Corporate Tax Base (CCTB) in order to implement a cohesive, mandatory corporate tax base definition and calculation system throughout the EU, and second, the CCCTB proposal builds upon the CCTB with additional measures for tax base consolidation and apportionment. ${ }^{184}$ Commentators view the updated CCTB proposal as a significant

175 See I.R.C. § 62(a); Amy B. Monahan, State Individual Income Tax Conformity in Practice: Evidence from the Tax Cuts \& Jobs Act, 11 ColuM. J. TAX L. 57 (2019).

${ }^{176}$ See, e.g., Mo. Rev. Stat. § 143.121.1.

177 Mo. ReV. STAT. § 143.121.2-6.

178 I.R.C. $§ 1001$.

${ }^{179}$ Germany Individual Income Determination - Capital Gains, PwC (Feb. 13, 2021), https://taxsummaries.pwc.com/germany/individual/income-determination [https://perma.cc/G9ZJ775H]. See also German Income Tax Act, (EStG) Einkommensteuergesetz in der Fassung der Bekanntmachung vom 8. Oktober 2009 (BGB1. I S. 3366, 3862), https://www.gesetze-iminternet.de/estg/BJNR010050934.html\#BJNR010050934BJNG000208140 [https://perma.cc/JEX46BEZ].

${ }^{180}$ See Infanti, supra note 7.

${ }^{181}$ See Luis C. Calderon Gomez, Transcending Tax Sovereignty and Tax Standardization: Three Questions, 45 YALE J. INT'L L. 191, 192 (2020).

182 The original CCCTB proposal was in 2011. Proposal for a Council Directive on a Common Consolidated Corporate Tax Base (CCCTB), COM (2011) 121 final (Oct. 6, 2011).

${ }^{183}$ Commission to the European Parliament and the Council Communication for A Fair and Efficient Corporate Tax System in the European Union: 5 Key Areas for Action, COM (2015) 302 final (June 17, 2015).

${ }^{184}$ See Proposal for a Council Directive on a Common Corporate Tax Base (CCTB), COM (2016) 685 final (Oct. 25, 2016); Proposal for a Council Directive on a Common Consolidated Corporate Tax Base (CCCTB), COM (2016) 683 final (Oct. 25, 2016). 
improvement with respect to its focus on tax fairness and commitment to combating base erosion, as it gives equal importance to non-taxation and under-taxation as it does to overtaxation. This compares to the 2011 CCCTB which was concerned primarily with overtaxation and reflected the European Commission's pro-market and pro-business emphasis in tax matters. ${ }^{185}$

Significant issues remain, however. Although harmonization envisions the resolution of tax competition due to transparent tax rate competition, there is some speculation that the proposal could in fact incentivize "factor-manipulation," which would allow artificial tax base shifting to continue. ${ }^{186}$ There is also concern that in leaving out tax rate coordination, member states are not sufficiently constrained from engaging in competition through corporate income tax rates to attract economic activity, ${ }^{187}$ and similarly, "[c]ountries may circumvent the common tax base by moving from allowances to tax credits as incentives." 188

The CCCTB project has a less ambitious objective and focuses on replacing transfer pricing guidelines with formulary apportionment. ${ }^{189}$ This approach presumably requires uniform income computation rules to develop an income apportionment formula. ${ }^{190}$ Application of the CCCTB proposal to MNEs would have undercut the argument that MNEs are at risk of multiple impositions of tax on the same income. The CCCTB apportionment formula would provide predictable outcomes and assure that each unit of income is taxable only in a single jurisdiction. However, Member States did not agree to the apportionment formula. ${ }^{191}$ The CCCTB proposal eliminated intangible property from the formula. With intangible property, the most fluid source factor of income apportionment removed from the formula, ${ }^{192}$ MNEs would have lost a principal tool for increasing the effective income apportionment to low tax jurisdictions. Only to the extent that the MNE has physical property, employees, or sales in a low tax jurisdiction does the formula apportion any of the MNE's income to the low tax jurisdiction. ${ }^{193}$

The CCCTB proposal is consistent with the assertion that representatives of MNEs frequently make that a reasonable level of taxation under unambiguous tax rules is acceptable as long as all MNEs are subject to identical and predictable rules so that none gain a competitive advantage through the tax system. The GloBE project similarly aligns well with assertions that there exists a concept of fair share or fair taxation. While the concept of fair share or fair taxation underlies recent discussions of a minimum tax, it is

${ }^{185}$ See Christian Valenduc, Corporate Income Tax in the EU, the Common Consolidated Corporate Tax Base (CCCTB) and Beyond: Is it The Right Way to Go? 18 (ETUI, Working Paper 2018.06, 2018) ("[S]ince 2011, the Commission has been moving from a tax policy agenda that was only 'pro-market' and 'pro-business' to a broader tax policy agenda that includes fairness and combating profit shifting and tax avoidance.").

${ }^{186}$ See Maarten F. de Wilde, Tax Competition Within the European Union Revisited - is the Relaunched CCCTB a Solution? 1 ERASMUS L. REV. 24 (2014).

${ }^{187}$ Hungary has a 9 percent, Ireland has a 12.5 percent, and Lithuania a 15 percent corporate rate, compared to France's 32 percent rate and Germany's 29.9 percent rate. Elke Asen, Corporate Income Tax Rates in Europe, TAX Found. (Apr. 16, 2020), https://taxfoundation.org /2020-corporate-tax-rates-in-europe/ [https://perma.cc/69EN-FERB].

188 See Valenduc, supra note 185, at 23.

189 Boer, Martin, A Few Comments on the CCCTB Directive 2-4 (Feb. 28, 2012)

(unpublished manuscript), https://ssrn.com/abstract=2012276 [https://perma.cc/7CQZ-R6S6].

${ }^{190} I d$. at 5 .

${ }^{191} \mathrm{Id}$. at 8 .

192 See 2011 CCCTB Proposal, supra note 17, at 14 (paragraph 21 of Preamble).

${ }^{193}$ See id. at 49 (article 86). Cf. Ordower, supra note 33, at 386. 
elusive and political. It lacks meaning other than as a politically relative concept supporting claims to a greater share of a limited resource. ${ }^{194}$ The reasonableness of a specific level of taxation should remain separate from the application of any nation's tax rules and the correct location for the imposition of the tax, that is, the question of which nation may collect that correct amount of tax. The premise that some correct amount or rate of taxation exists underpins all the BEPS iterations that conclude that MNEs ought to pay more tax than they do currently. While a general notion of a universally correct level of taxation may exist and each MNE and possibly each individual should be subject to that level, some (or many) MNEs and individuals are not paying that correct level. Yet, the BEPS projects are not geographically neutral in their approach to collecting the fair amount of tax but conflate the fair tax concept with geographic determinations that the MNEs are avoiding taxes imposed by the developed economies. ${ }^{195}$ That approach politicizes the concept of fairness rather than seeking consensus concerning the correct level of taxation free from the political issue of which nation gets the revenue. ${ }^{196}$

\section{THE RELATIVE AND ABSOLUTE POVERTY CONUNDRUM}

Once OECD participants agree to an anti-profit shifting structure, MNEs in the aggregate will pay additional tax. Whether residence, consumption, or another metric becomes the measuring instrument to prevent profit shifting, income will be allocated so that MNE's can no longer concentrate revenue in low tax jurisdictions that are not contributing more than a minimal amount to the production of the income. Allocation factors such as labor measured by person-hours rather than wages, ${ }^{197}$ international market sale value of resources rather than extraction value or some other value-added measurement ${ }^{198}$ may direct a somewhat greater share of worldwide profit to less developed economies. A minimum tax will limit the ability of less developed economies to trade their power to collect taxes for investment. Under all structures under discussion internationally, the developed economies are likely to enjoy the bulk of the reallocated or increased tax bases and gain additional tax revenue.

History suggests that some developed countries will deploy the additional revenue for the good of all residents while others will follow a course of concentrating benefits through reduced tax impositions into the hands of the affluent under the premise that the affluent create jobs for the less affluent members of society. ${ }^{199}$ How the incremental revenue is utilized, it is reasonably certain that little of it will find its way to international development, ${ }^{200}$ and the disparity between rich and poor nations and their citizenries seems likely to increase. Just as leveling of revenue among St. Louis County taxing districts to smooth wealth disparities among districts on even such an essential resource as public

${ }^{194}$ Brassey \& Ordower, supra note 37, at 100-02.

${ }^{195}$ Sarah Paez, Groups Urge U.N. Tax Committee to Reconsider OECD Unified Approach, TAX Notes TODAY INT'L (June 17, 2020), https://www.taxnotes.com/tax-notes-todayinternational/base-erosion-and-profit-shifting-beps/groups-urge-un-tax-committee-reconsider-oecdunified-approach/2020/06/17/2cmnh [https://perma.cc/FZ7V-GYWM].

${ }^{196}$ See Brassey \& Ordower, supra note 37.

${ }^{197}$ Ordower, supra note 33, at 387-88.

${ }^{198}$ Christians \& van Apeldoorn, supra note 32, at 29-39.

199 See David Hope \& Julian Limberg, The Economic Consequences of Major Tax Cuts for the Rich (LSE Int'l Ineq. Inst., Working Paper 55, 2020). https://eprints.lse.ac.uk/107919/1 /Hope_economic_consequences_of_major_tax_cuts_published.pdf [https://perma.cc/4CS6-GPEG] (empirical study on effects of major tax cuts for the rich on income inequality, economic growth, and unemployment).

${ }^{200}$ Brassey \& Ordower, supra note 37 , at 102-04. 
education rarely if ever captures the center of attention in public debate, ${ }^{201}$ international revenue distribution to level resource allocation internationally rarely if ever becomes the center of tax reform debate internationally despite the absence of a moral, rather than political, justification for such resource disparities. ${ }^{202}$ Many resource and wealth disparities are functions of the happenstance of serendipitous geographic location for some populations.

The 2020 COVID-19 pandemic is likely to augment the numbers of homeless individuals in the U.S. as unemployment renders large numbers of Americans unable to meet their residential rent or mortgage obligations. ${ }^{203}$ School closings have left many children without adequate nutrition because they no longer receive the daily meals at school on which they relied for basic nutrition. ${ }^{204}$ The need for food, shelter, clothing, and healthcare in the U.S. is great ${ }^{205}$ but the need is primarily a distribution issue. Since the U.S. is a principal world food exporter ${ }^{206}$ food resources in the U.S. should be adequate for the population. Even the welfare states of Europe have residents in need of support for basic needs. Poverty exists in all the OECD member states and it is inexcusable. On a global scale, poverty in developed economies rarely compares with the absolute poverty that plagues many undeveloped or developing economies. ${ }^{207}$ In some countries, people, often children, die from starvation. ${ }^{208}$ Diseases like malaria that disable and kill many in less developed countries could be controlled or eradicated given sufficient economic resources and commitment. While fatal hunger is relatively absent in economically developed countries, fatal hunger may be ubiquitous in some less developed countries. Homelessness, shortages of clothing, and limited educational opportunities are all prevalent in economically developed countries, as well as less developed and undeveloped economies, but in developed economies the housing, clothing, and education shortages are primarily a matter of resource distribution rather than lack of resources. In undeveloped economies, the shortages are more likely to be structural.

${ }^{201}$ See supra Part II.

202 See Ivan Ozai, Inter-Nation Equity Revisited, 12 Colum. J. TAx L. 58 (2020).

${ }^{203}$ See Glenn Thrush, Homelessness in U.S. Rose for 4th Straight Year, Report Says, N.Y.

Times (Mar. 18, 2021), https://www.nytimes.com/2021/03/18/us/politics/homelessnesscoronavirus.html [https://perma.cc/R2NQ-6F48].

${ }^{204}$ Mary Kathryn Poole et al., Addressing Child Hunger When School Is ClosedConsiderations During the Pandemic and Beyond, NEJM.ORG (Mar. 11, 2021), https://www.nejm.org/doi/full/10.1056/NEJMp2033629 [https://perma.cc/UJ5P-MF3P].

205 Facts about Poverty and Hunger in America, FEEDING AMERICA, https://www.feedingamerica.org/hunger-in-america/facts\#: :text=More\%20than\%2037\%20million \%20people,to\%20support\%20a\%20healthy\%20life [https://perma.cc/E96J-FR5T] (last visited July $10,2020)$ (37 million in the U.S. suffer from food insecurity).

206 Which Countries Export the Most Food? WORLD ATLAS, https://www.worldatlas.com/articles/the-american-food-giant-the-largest-exporter-of-food-in-theworld.html [https://perma.cc/HT5G-NAWF].

207 Global Issues, Food, UN, https://www.un.org/en/sections/issues-depth/food/index.html [https://perma.cc/9TBM-LRKP] (last visited July 10, 2020) (estimating 821 million people suffering from hunger in 2018).

208 The World Counts estimates that 9 million people die each year from starvation. People Who Died from Hunger, WORLD COUNTS, https://www.theworldcounts.com/challenges/people-andpoverty/hunger-and-obesity/how-many-people-die-from-hunger-each-year

[https://perma.cc/U9DG-QTYS] (last visited July 10, 2020). In 2015, it was estimated that 10\% of the worldwide population were living in conditions of extreme poverty. Decline of Global Extreme Poverty Continues but has Slowed: World Bank, THE World BANK (Sept. 19, 2018), https://www.worldbank.org/en/news/press-release/2018/09/19/decline-of-global-extreme-povertycontinues-but-has-slowed-world-bank [https://perma.cc/77G5-ATAA]. 
Poverty in the OECD countries is relative. ${ }^{209}$ Relative to many in the developed countries' societies or the OECD states in general, some residents have little wealth and suffer by comparison with those who are affluent. But poverty in the developed world is not absolute. ${ }^{210}$ Like the U.S., each of the OECD countries probably has adequate resources to eliminate the relative poverty in that OECD country by redeploying existing resources, without receiving additional tax revenue from MNEs. Many less developed countries could not address the poverty they have without substantial assistance from the affluent countries, but the affluent countries have offered only nominal aid relative to their gross national incomes ${ }^{211}$ and national budgets. Most devote less than one percent of their gross national income to international development to provide relief from poverty. ${ }^{212}$

Under such circumstances, private, altruistic actors such as Bill and Melinda Gates through their foundation ${ }^{213}$ and business interests wanting natural resources or inexpensive labor drive development in nations suffering much absolute poverty. ${ }^{214}$ A non-affluent country might seize the opportunity for private, inbound investment by supplementing the competitive advantage of local low-cost labor with an agreement not to tax the investment capital or the earnings from that investment. Zero tax, perhaps accompanied by other investment incentives, may provide the nudge to the international investor to invest in that non-affluent country rather than another non-affluent jurisdiction that does not offer exemption from local taxation. If taxing the MNE might cause the MNE to take its investment capital to another non-affluent country offering lower taxes or no tax, relinquishing the potential tax revenue seems like an easy choice. Despite their exploitation by low wages, such low wage employment for residents alleviates the absolute poverty from which those newly employed residents previously may have suffered. ${ }^{215}$ If child labor best meets the international concern's labor requirements, children often work,

${ }^{209}$ See Koen Caminada et al., Social income transfers and poverty: A cross-country analysis for OECD countries, INT'L J. SOC. Welfare (Apr. 2012), https://www.researchgate.net/publication/227690060_Social_income_transfers_and_poverty_A_cr oss-country_analysis_for_OECD_countries[https://perma.cc/ZBQ4-FDBG].

${ }^{210}$ Brassey \& Ordower, supra note 37, at 104.

211 See Gross National Income Data, OECD, https://data.oecd.org/natincome/grossnational-income.htm [https://perma.cc/Q7PX-Y22D] (last visited July 10, 2020) ("Gross national income (GNI) is defined as gross domestic product, plus net receipts from abroad of compensation of employees, property income and net taxes less subsidies on production.").

212 Official Development Assistance as a Percentage of Gross National Income (GNI): Net disbursement, all donors, OECD International Development Statistics, Volume 2018 Issue 1, OECD (2019), https://doi.org/10.1787/dev-v2018-1-table3-en [https://perma.cc/9HZ9-RWNA] (last visited Jun. 16, 2020).

213 Foundation Fact Sheet, Bill \& Melinda Gates Found., https://www.gatesfoundation.org/Who-We-Are/General-Information/Foundation-Factsheet [https:// perma.cc/H7NF-XA6Z] (last visited July 10, 2020).

${ }^{214}$ Fashion Victims- The Facts, WAR ON WANT, https://waronwant.org/fashion-victimsfacts [https://perma.cc/UC2H-PK8E] (last visited July 10, 2020) (clothing factories in Bangladesh and India); John Vidal, How Developing Countries are Paying a High Price for the Global Mineral Boom, GuARDiAn (Aug. 15, 2015), https://www.theguardian.com/global-development/2015 /aug/15/developing-countries-high-price-global-mineral-boom [https://perma.cc/7VP5-ATMF].

${ }^{215}$ See Fashion Victims, supra note 214. In some instances, the populace of a low wage country may suffer such exploitation from MNEs in low wages, long hours and poor working conditions that it may have been better off before the investment with subsistence farming or even such occupations as trash picking. 
perhaps without the knowledge of the MNE, to assist their impoverished families despite international labor standards that outlaw child labor. ${ }^{216}$

The OECD projects, like U.S. worldwide taxation, might deprive the non-affluent country of the opportunity to capture the investment with the assistance of tax concessions. Even if the non-affluent country manages to secure the investment and, under notions of value creation, ${ }^{217}$ the tax base distribution formula which allocates a significant share of the income of the MNE to the non-affluent jurisdiction, that jurisdiction might not have the necessary infrastructure to measure the MNE's income, impose, and collect the tax. The non-affluent country historically may have relied on VATs or targeted taxes, like natural resource extraction taxes, for example, rather than more complex tax bases like an income tax. The non-affluent jurisdictions may have an inadequate administrative infrastructure for such a tax. The newly tax-base-enriched jurisdiction in some instances simply may rely on or piggyback onto the computations that the affluent home country might perform. Even in instances in which the non-affluent country relies on the tax infrastructure of developed economies, local collection of the tax may necessitate additional tax collection administration the country can ill afford. Collection may prove inefficient and open the door to additional corruption exacerbating existing inefficiencies and corruption in the nonaffluent country's tax infrastructure.

The non-affluent country could choose not to collect the minimum tax, leaving the revenue on the table for the MNE's home country to take, but that would seem foolish. Persuading some non-affluent countries to collect tax which MNEs' home countries otherwise would collect may drive those countries to create unofficial and perhaps corrupt schemes to aid the MNEs to avoid their home country taxes. ${ }^{218}$ Some MNEs might accede to such schemes to meet competitors who already participate in such tax avoidance or even evasion and were drawn to the schemes by the promise of enhanced profitability. The result of the imposition of the GLoBE pillars in the end might mimic historical iterations of tightened tax regulation being met with sophisticated tax planning that remains one step ahead of the tax legislators and administrators and devises strategies of varying legality to avoid new tax regulation. ${ }^{219}$

If the developed OECD economies wish to enrich affluent state coffers by seizing additional tax revenue from MNEs, the OECD projects may begin to accomplish that goal. If, on the other hand, the OECD membership is offended by the success of MNEs in avoiding the relatively high taxes of the developed economies and has identified a "fair tax" amount that each MNE should pay, without regard to which country receives the revenue, the OECD projects also may begin to accomplish that goal. If, however,

${ }^{216}$ See Emma Aisbett et al., Do MNCs Exploit Foreign Workers? 38-39 (Nov. 27, 2019) (unpublished manuscript) (on file with The Brookings Institution), https://www.brookings.edu/wpcontent/uploads/2019/12/Aisbett-et-al._Brookings-draft-2019.11.26_Harrison.pdf [https://perma.cc /4DMW-JZ5L]; Danny Zane et al., Why Companies Are Blind to Child Labor, HARv. Bus. Rev. (Jan. 28, 2016), https://hbr.org/2016/01/why-companies-are-blind-to-child-labor [https://perma.cc/RZ3VCNM4]; Sarah Boseley, Child Labour Is Never OK. But for Multinationals It Is an Outrage, GUARDIAN (June 26, 2018), https://www.theguardian.com/commentisfree/2018/jun/26/child-labour -tobacco-fields-multinationals-life-chances-destroyed [https://perma.cc/P557-6DKM].

${ }^{217}$ See Christians \& van Apeldoorn, supra note 32, at 29-39.

${ }^{218}$ See, e.g., OECD HARMFul TAX COMPETITION, supra note 12, at 24 (lack of effective information exchange from tax haven jurisdictions limits timely application and collection of tax by non-tax haven jurisdictions); I.R.C. $§ 1471$ (denying benefits to foreign financial institutions that are uncooperative).

${ }^{219}$ See Ordower, supra note 42, at 48. 
distribution of the "fair tax" revenue in aid of international development to eliminate absolute poverty and level resources globally is the goal of enhanced tax collections, as it should be, fairer allocation of the tax base itself might do little toward that end. Instead, uniform tax collection and tax revenue distribution would seem a better choice. The next section imagines an international taxing agency applying uniform tax rules to collect revenue and eliminate tax arbitrage opportunities available due to the multiplicity of taxing jurisdictions.

VI. AN INTERNATIONAL TAXING AGENCY FOR AN ECONOMICALLY GLOBALIZED WORLD: ABANDONING MYTHICAL TAX SOVEREIGNTY

All base erosion projects require some compromise of tax sovereignty, a topic overdue for more serious consideration insofar as sovereignty in taxing well may be a false flag in the world of tax treaties, tax information exchange agreements, and tax blacklists designed to coerce non-cooperative jurisdictions into becoming cooperative. The business world has long accustomed itself to operating across international borders and within the framework of multiple sovereign states. Income tax systems of nations participating in the OECD Inclusive Framework addressing base erosion and profit shifting must converge to smooth and eliminate systemic disparities so that base erosion in one state is not simply a structural element of another. Lack of tax base uniformity may facilitate new base erosion as taxing units adjust their bases rather than their rates to engage in tax competition. ${ }^{220} \mathrm{~A}$ minimum rate of tax requires uniformity of the base for the tax and uniform administration of the tax to attain its goal, but existing minimum tax proposals fail to require the essential uniformity. Each step toward uniformity requires nations to compromise their tax sovereignty and accept a compromise position that may accommodate or follow another nation's tax rules. The ideal way to guarantee that uniformity of rules and administration would be a single international agency to administer the common rules with powers to operate independently of national borders. Measurement of income under uniform substantive and procedural rules is essential but the determination of income source or taxpayer residence would become matters of revenue distribution, not tax collection. The international agency may collect the taxes and distribute them among nations under an internationally determined formula that is not dependent on the determination of income source or residence.

Much sovereignty is at stake in the BEPS and GloBE projects but voluntary relinquishment of sovereignty is not novel. Nor does it represent a radical change from historic practices during the $20^{\text {th }}$ century. Following World War I, the League of Nations emerged as a mechanism for international cooperation and resolution of disputes that would avert future wars. It failed, of course, but the United Nations followed the next world war. UN peacekeeping interventions have prevented some wars ${ }^{221}$ but the UN has not spoken with sufficient authority to supplant sovereign decision-making that threatens peaceful intercourse among nations.

${ }^{220}$ See de Wilde, supra note 186 , at 30 ("[U]nitary approach ... reflecting inputs and outputs is generally considered to produce less opportunity for engaging in artificial tax avoidance operations.").

221 Our Successes, UN PEACEKEEPING, https://peacekeeping.un.org/en/our-successes [https://perma.cc/QD5Y-37BJ] (last visited June 18, 2020); Mano River Basin, 25 Years of Peacekeeping, UN PEACEKEEPING, https://peacekeeping.un.org/en/mano-river-basin-25-years-ofpeacekeeping (last visited June 18, 2020). 
Common economic interests have been somewhat more successful in securing international cooperation. The World Trade Organization (WTO), ${ }^{222}$ for example, promotes international trade and provides a forum for the resolution of trade disputes and represents a compelling example of international cooperation for common economic interests. ${ }^{223}$ Even the U.S. has acquiesced in adverse decisions of the WTO concerning anti-competitive practices and impermissible subsidies. ${ }^{224}$ Both the EU, which began as an economic community to regulate and promote trade for the benefit of its members, ${ }^{225}$ and the Union of Soviet Socialist Republics (USSR) ${ }^{226}$ were created during the twentieth century. Each required ethnically and linguistically discrete countries to cede more or perhaps less voluntarily in the case of the USSR considerable economic independence to secure improved economic and trade relations beneficial for all member states. Central planning in the USSR, government control over many aspects of daily life, slow economic growth, and restrictions on individual liberties contributed to the eventual failure of the USSR model, ${ }^{227}$ while limited central government control, protections of individual liberties and national independence, as opposed to EU common interests, in many nontrade related functions has worked with considerable success in the EU model. The UK's withdrawal from the $\mathrm{EU}^{228}$ and dissension with respect to several primarily non-economic or trade issues including immigration ${ }^{229}$ indicates that the EU model may require adjustments for it to endure permanently without loss of additional member states. Nevertheless, the willingness of nations to acquiesce in the authority of an international and voluntary administrative body to promote common economic interests exists. On a

222 What is the WTO?, WORLD TRADE ORGANIZATION, https://www.wto.org/english /thewto_e/whatis_e/whatis_e.htm [https://perma.cc/Y4S7-6DXU] (last visited July 10, 2020).

${ }^{223}$ Martin Vallespinos, Can the WTO Stop the Race to the Bottom? Tax Competition and the WTO, 40 VA. TAX REV. 93 (2020) (arguing that the WTO should police tax concessions because they impact trade).

${ }^{224}$ See, e.g., Press Release, European Commission, WTO Boeing dispute: EU issues preliminary list of U.S. products considered for countermeasures (Apr. 17, 2019), https://ec.europa.eu/commission/presscorner/detail/en/ip_19_2162 [https://perma.cc/69Y9-SKAB]; Press Release, Office of the United States Trade Representative, U.S. Notifies Full Compliance in WTO Aircraft Dispute (May 6, 2020), https://ustr.gov/about-us/policy-offices/press-office/pressreleases/2020/may/us-notifies-full-compliance-wto-aircraft-dispute [https://perma.cc/BK6W3Z7H]. See also Appellate Body Report and Panel Report, United States Tax Treatment for "Foreign Sales Corporations, ” WTO Doc. WT/DS108/36 (Mar. 17, 2006) (the U.S. repealed the grandfather provisions of the American Jobs Creation Act and the ETI Act that were subject to compliance proceedings); Appellate Body Report and Panel Report, United States - Import Prohibition of Certain Shrimp and Shrimp Products, WTO Doc. WT/DS58/23 (Nov. 26, 2001).

225 The History of the European Union, EUROPEAN UNION, https://europa.eu/europeanunion/about-eu/history_en [https://perma.cc/2QM3-FQGR] (last visited June 18, 2020).

226 See generally, Soviet Union, ENCYC. BRITTANICA, https://www.britannica.com /place/Soviet-Union [https://perma.cc/2C9R-VM4B] (last visited July 27, 2020).

${ }^{227}$ See Numa Mazat, Structural Analysis of the Economic Decline and Collapse of the Soviet Union, ANPEC (2016) https://www.anpec.org.br/encontro/2015/submissao/files_I/i3186e370d13d34b7043cb737da8d75390.pdf [https://perma.cc/5HE7-9JDQ]; Michael Ray, Why Did the Soviet Union Collapse? BRITTANICA, https://www.britannica.com/story/why-did-the-sovietunion-collapse [https://perma.cc/DW4A-443J].

${ }^{228}$ Brexit - UK's Withdrawal from the EU, EUR-LEX, https://eur-lex.europa.eu/content /news/Brexit-UK-withdrawal-from-the-eu.html [https://perma.cc/Y2W9-65QW] (last visited June $18,2020)$.

${ }^{229}$ See, e.g., Pablo Gorondi, Hungary's Orban Critical of EU Leaders on Migration, Economy, AP News (July 27, 2019), https://apnews.com/b89e682583014c7e8a1bf1cbb46e5dcf [https://perma.cc/EKM9-59BJ]. 
small scale, five economic powers have joined in a combined effort to reduce tax evasion. ${ }^{230}$

In many countries, business interests, politicians, and the populace regularly malign the taxing agencies while simultaneously looking to the taxing agency to subsidize the activities and interests they favor. In the U.S., even members of Congress refer to the tax laws as the "IRS code," ${ }^{231}$ implicitly assigning responsibility for taxation to the administrative agency as if it, and not the legislature, were responsible for the tax laws that the agency must enforce. Congress and other national legislatures have grown accustomed to delivering indirect subsidies through the tax law rather than directly subsidizing activities and interests. ${ }^{232}$ While an international taxing agency enforcing internationally uniform tax rules under uniform administrative procedures and standards might continue to be a subject of derision, it would remove taxation from the domestic political sphere and allow it to serve its primary function of raising the revenue necessary to operate governments, rather than as an indirect source of funding for private activities.

By separating taxation from domestic politics, international uniformity diminishes the opportunism of targeted tax subsidies and requires discussion of budgeting for a subsidy with a direct expenditure rather than the current indirect delivery through decreased tax liability. Many tax subsidies currently are opportunistic and frequently provide taxpayers' the opportunity to misdirect all or part of the intended subsidy. ${ }^{233}$ They result from the exertion of influence by limited interests and appear in statutory language that is deceptively general despite being targeted to the influential interests. ${ }^{234}$ Changing tax rules under an internationalized system to subsidize specific business interests would require international agreement and is likely to be far less common than such subsidies are now.

Uniform taxation of income without regard to source and divorced from the distribution of the centrally collected tax revenue among nations eliminates the need for bilateral or multilateral tax treaties, as well as TIEAs, except for the general agreement to be part of the unified tax system and to acquiesce in the distribution formula. Where a

${ }^{230}$ Joint Chiefs of Global Tax Enforcement, IRS, https://www.irs.gov/compliance/jointchiefs-of-global-tax-enforcement [https://perma.cc/2LB2-RL7M] (last visited July 14, 2020).

${ }^{231}$ Michelle Ye Hee Lee, Who wrote the 'IRS code'? Hint: It wasn't the Internal Revenue Service, WASH. POST (Apr. 13, 2015), https://www.washingtonpost.com/news/fact-checker /wp/2015/04/13/who-wrote-the-irs-code-hint-it-wasnt-the-internal-revenue-service/ [https://perma.cc/P7KQ-GKG4].

232 See U.S. DeP'T OF TREAS., TAX EXPENDITURES (2018), https://home.treasury.gov /system/files/131/Tax-Expenditures-FY2020.pdf [https://perma.cc/3DF2-6K54] [hereinafter Tax Expenditures].

${ }^{233}$ See Henry Ordower, Capital, an Elusive Tax Object and Impediment to Sustainable Taxation, 23 FLA. TAX REV. 625, 630-32 (2020). For contrary views approving the use of the taxing authority for non-revenue functions, see, for example, David A. Weisbach \& Jacob Nusim, The Integration of Tax and Spending Programs, 113 YALE L. J. 955 (2004) and Sara Sternberg Greene, The Broken Safety Net: A Study of Earned Income Tax Credit Recipients and a Proposal for Repair, 88 N.Y.U. L. REV. 515 (2013).

${ }^{234}$ See, e.g., I.R.C. $\S \S 1400 Z-1,1400 Z-2$; Subcommittee on Econ. \& Consumer Pol'y, U.S. House of Representatives, Lawmakers Question Mnuchin on Possible Opportunity Zone Abuse, TAX NOTES TODAY FED. (June 24, 2020), https://www.taxnotes.com/tax-notes-today-federal/opportunityzones/lawmakers-question-mnuchin-possible-opportunity-zone-abuse/2020/06/25/2cnd8?highlight $=$ opportunity\%20zones [https://perma.cc/TN9Y-MRDA]; Brett Theodos, Jorge Gonzalez \& Brady Meixwell, The Opportunity Zone Incentive Isn't Living Up to Its Equitable Development Goals. Here Are Four Ways to Improve It, URBAN WIRE (June 17, 2020), https://www.urban.org/urbanwire/opportunity-zone-incentive-isnt-living-its-equitable-development-goals-here-are-four-waysimprove-it [https://perma.cc/K99C-A7CX]. 
taxpayer earns income will no longer determine to whom the income is attributable and who has the taxing authority. Income from intangible property that is currently so abstract, fluid, and challenging to source ceases to be so. If there is income, it is taxable under the uniform rules of taxation. Outlier jurisdictions that do not join in the centralized taxing regime are minimally problematic. Sourcing rules for the unified jurisdiction would include a range of connections - property, labor, revenue (direct or indirect), and residence of owners or beneficiaries. A taxpayer would be free from the agency's taxing jurisdiction only if they did nothing directly or indirectly outside the residence jurisdiction that has not joined the centralized tax regime and the outlier country would receive no part of the centrally collected tax revenue. An investment in any country that is part of the unified taxing agency collection by an entity based in a non-cooperating jurisdiction would be a sufficient connection with the unified taxing jurisdiction to render the taxpayer's income taxable by the unified agency.

Constructing uniform rules and assembling agreement will be a formidable task, but the project would have the virtue of binding uniformity that current international projects lack. When a country signs on to the agreement, it has little room to manipulate the rules since it will delegate tax administration and collection to the independent international agency in which all countries are represented. ${ }^{235}$ Robust related-party rules will limit the ability of taxpayers to arbitrage progressive rates with multiple entities. ${ }^{236}$ Universal tax transparency so that a single tax would be imposed at the ultimate ownership level might be most sensible but perhaps too difficult to administer. ${ }^{237}$ Mechanisms for broad-based information reporting by financial institutions, vendors, and business consumers are critical to enforcement, and a more extensive withholding system than currently in place in most countries certainly would facilitate accurate reporting. Perhaps most important would be an international, public education effort so that taxpayers worldwide receive identical and accurate messages concerning the benefits of the global system, its uniformity, and its system for currency translation to achieve economic uniformity to address hyper-inflationary currencies. Supplemental to the global system and beneficial to worldwide economic stabilization that should follow from the distribution formula would be currency exchange rate stabilization and possible transition to a single international currency.

For MNEs, a single tax collector and single computation would be likely as well to facilitate a transition to a uniform international accounting and reporting system to replace the awkward reporting split between the generally accepted accounting principles (GAAP) that the U.S. uses and the international financial accounting standards (IFRS) in

${ }^{235} \mathrm{Cf}$. Ordower, supra note 33 , at 375-78.

${ }^{236}$ Cf. I.R.C. $\S 318$ (constructive ownership rules); I.R.C. $§ 267$ (b) (related parties for loss denial). There are many other such provisions using a variety of thresholds for treating otherwise separate individuals or entities as having common interests that limit tax separation.

${ }^{237}$ Extensive tax transparency exists in the U.S. as the income of partnerships and limited liability companies. See I.R.C. $\S 701$; I.R.C. $\$ 1361$ (for electing S corporations); Treas. Reg. $\$ 301.7701-3$ (non-U.S. entities that make election are taxable only to the underlying owners). Commentators, including the author of this Article, have recommended full tax transparency for corporations. See Henry Ordower, Preserving the Corporate Tax Base through Tax Transparency, 71 Tax Notes InT’L 993 (Sept. 9, 2013). Modified transparency also exists. See I.R.C. § 851 (regulated investment companies); I.R.C. $§ 857$ (real estate investment trusts) 
use in much of the remainder of the world. ${ }^{238}$ The U.S. finally might transition to IFRS as has been proposed, but not finalized, by the Securities and Exchange Commission. ${ }^{239}$

VII.

\section{REVENUE SHARES}

One virtue of global tax administration under uniform tax rules is that taxpayers are left with no place to hide from paying taxes. Taxation under this system is borderless. Tax planners undoubtedly will continue to seek, and perhaps occasionally discover, opportunities to diminish their clients' tax liability, but borderless uniformity ideally eliminates all opportunities to reduce taxes by redirecting income or income-producing activity to other jurisdictions. Globally centralized determination and collection of tax likewise precludes local political decision-making from impacting tax liability and delivering benefits through the tax system.

The premise that a fundamental concept of fair taxation exists free from political determinants underlies common global tax collection under uniform rules. "Fair share" becomes a global rather than domestic concept. Each taxpayer should pay their "fair share" relative to global, not national, revenue needs. A global "fair share" concept recognizes that even economic activity that may seem local is not. Rather, under uniform taxation and collection, global economic and social interdependency would be recognized universally and could emerge as the ultimate marker of the $21^{\text {st }}$ century. The COVID-19 pandemic, worldwide commercial branding and manufacturing, ${ }^{240}$ international terrorism ${ }^{241}$, and cross-border intrusion into elections and the political process ${ }^{242}$ are only a few of the many elements that demonstrate how inextricably intertwined nations have become.

238 See Lisa Weaver, The Wider Implications of Transitioning to IFRS-10 Things to Consider, IFAC (Dec. 3, 2014), https://www.ifac.org/knowledge-gateway/supporting-internationalstandards/discussion/wider-implications-transitioning-ifrs-10-things-consider\#: :text=The $\% 20$ transition $\% 20$ to $\% 20$ International $\% 20$ Financial,reporting $\% 20$ in $\% 20$ the $\% 201$ ast $\% 20$ decade [https://perma.cc/67MM-E4Q9].

${ }^{239}$ SEC Unanimously Approves Exposing Proposed IFRS Roadmap for Public Comment, AICPA (Aug. 27, 2008), https://www.ifrs.com/updates/sec/SEC_approves.html [https://perma.cc /KL7R-WZV7].

${ }^{240}$ Claire Matthews, What is the Secret to McDonald's Global Branding Success, MAISTRO (Nov. 5, 2014) https://blog.maistro.com/procurement/secret-mcdonalds-global-branding-success [https://perma.cc/S9T9-QNVD]; Sean Galea-Pace, Inside adidas' Supply Chain, SuPPLy ChaIN, https://www.supplychaindigital.com/supply-chain/inside-adidas-supply-chain [https://perma.cc/5DJY-DCGK] (last visited June 29, 2020).

${ }^{241}$ Pamela Engel \& Ellen Loanes, What Happened on 9/11, 18 Years Ago, Bus. InSIDER (Sept. 10, 2019), https://www.businessinsider.com/what-happened-on-911-why-2016-9 [https:// perma.cc/WUD5-YUKS]; History, Famous Cases \& Criminals, Pan Am 103 Bombing, FBI, https://www.fbi.gov/history/famous-cases/pan-am-103-bombing [https://perma.cc/WN8L-6DJZ] (last visited June 23, 2020); Simon Burton, 50 Stunning Olympic Moments No 26: The Terrorist Outrage in Munich in 1972, GUARDIAN (May 2, 2010), https://www.theguardian.com/sport /blog/2012/may/02/50-stunning-olympic-moments-munich-72 [https://perma.cc/K4YC-ADFG].

${ }^{242}$ See Off. of the DiR. Of Nat'l InTElligence, Assessing Russian Activities AND INTENTIONS IN RECENT U.S. ELECTIONS (2017), https://assets.documentcloud.org/documents /3719492/Read-the-declassified-report-on-Russian.pdf [https://perma.cc/M4JQ-EJUP]; Joshua Kurlantzick, How China is Interfering in Taiwan's Election, CounCIL ON ForeIGN Rel. (Nov. 7, 2019) https://www.cfr.org/in-brief/how-china-interfering-taiwans-election [https://perma.cc/A6DK3JLV]. 
The impetus to the OECD Action plans, ${ }^{243}$ the EU's list of tax haven jurisdictions,${ }^{244}$ and FATCA in the U.S. ${ }^{245}$ relies on a more limited and domestic thesis. The thesis is that MNEs and other taxpayers misdirect some of their income to low tax jurisdictions to avoid paying the amount of income tax they should pay into the treasuries of major developed economies. Under that thesis, the notion of fair taxation is relative and location-specific. It is valid only insofar as it defines the amount a taxpayer should pay to a specific developed nation's treasury. The OECD framework purports to be more global. ${ }^{246}$ but it emphasizes capturing additional revenue for the treasuries of the developed economies. Failing enhancement of tax revenue for those developed economies, the OECD's leading member nations might lose interest in collecting additional tax from the MNEs targeted by the BEPS Actions.

Rule uniformity and central global tax collection postulates an alternative to the location-specific thesis expressed in the preceding paragraph. The alternative thesis is more abstract and independent of location. It posits the existence of a global responsibility to provide each individual with sufficient resources to secure a decent standard of living. Whether that view arises from a universal human value system that demands a just world without poverty or from a sense of self-preservation that foresees physical and economic risks to those with wealth from those who are impoverished, ${ }^{247}$ the thesis requires that each taxpayer pay a correct amount of tax that depends on the taxpayer's characteristics. Those characteristics might include the taxpayer's ability to pay measured under the common standard of the taxpayer's income from all sources worldwide as compared with all other taxpayers. Under such a thesis, the major developed economies might support a collection of that fair share even if the additional tax does not augment their governmental coffers.

Both the OECD Actions and FATCA are designed to generate additional tax revenue by redirecting income from its artificial location in a low tax jurisdiction to its correct location in a higher taxed, major developed economy. Neither the OECD Actions nor FATCA favors one higher tax jurisdiction over another insofar as neither redirects the incidence of taxation as long as the rate imposed is sufficiently high. For example, the BEPS actions would not redirect income from the Netherlands to Germany because both countries impose a sufficiently high rate of tax, but BEPS might redirect income from Ireland to Germany because the Irish corporate rate is only 12.5 percent. Similarly, FATCA might include income from offshore investments in a U.S. taxpayer's income but, except under unusual circumstances where the tax is payable to a diplomatically restricted country, ${ }^{248}$ would allow the U.S. taxpayer a credit for the tax paid to the other jurisdiction. ${ }^{249}$ A common international taxing system with uniform rules and administration similarly will produce more income tax revenue than is generated

${ }^{243}$ See supra Part III.

${ }^{244}$ See EU List of Non-cooperative Jurisdictions, supra note 15.

${ }^{245}$ See FATCA $\S \S 1471-1474$, 6038D (underlying principle of FATCA acknowledging that U.S. taxpayers that hide assets abroad need ferreting out).

246 See OECD/G20 InCLUSIVE FRAMEWORK ON BEPS, supra note 122, at 26.

247 See Meetings Coverage, General Assembly 86 ${ }^{\text {th }}$ Meeting, Links between Extreme Poverty, Violent Extremism Can Be Broken by Creating Jobs, Reducing Inequalities, General Assembly Hears as Debate Concludes, GA/11761 (Feb. 16, 2016); Ian Black, Poverty Driving Syrian Men and Boys into the Arms of Isis, GUARDIAN (May 4, 2016), https://www.theguardian.com/globaldevelopment/2016/may/04/poverty-driving-syrian-men-and-boys-into-the-arms-of-isis

[https://perma.cc/C7TW-VP67].

${ }^{248}$ I.R.C. $\S 901(\mathrm{j})$.

${ }^{249}$ I.R.C. $§ 901(a)$. 
worldwide if current developed economy rates apply. Estimates of the amount of additional revenue vary both with rates and assumptions. ${ }^{250}$ The amount of additional tax revenue from preventing profit shifting ${ }^{251}$ or reducing the tax gap ${ }^{252}$ is not trivial even if speculative. ${ }^{253}$ While developed economies do use their tax systems politically to deliver a considerable array of incentives, it nevertheless would seem to be in their interests to join a borderless tax consortium to promote fair and even-handed taxation of all participants in the economy and to augment global tax revenue production. Political quibbling among advanced economies, of course, might stymie agreement as it has on adopting even a simple measure like the CCCTB.

With limited exceptions for a few developed economies like Ireland that use their tax rates and structures to attract foreign investment, ${ }^{254}$ the countries that rely most heavily on tax rates and concessions to attract investment fall into two broad groups. One group consists of countries with many poor, often absolutely poor, residents. Those countries look to international investment for the basic development of infrastructure and provision of human essentials and jobs. They tend to lack strong bargaining power for international investment and readily offer privileges, including freedom from taxation, to international investors. ${ }^{255}$ A second group of countries are the more traditional tax haven countries, frequently island jurisdictions, with developed business or investment servicing infrastructures without the need for substantial tax revenue to carry their infrastructures. Some of the groups have significant tourist industries and raise revenue through consumption taxes like hotel and meal taxes targeted at tourists. The issue for a borderless uniform income tax is how to attract those countries to join the tax consortium.

For countries that rely on their low tax structure to capture international investment, the revenue distribution formula under a borderless uniform tax has to place these countries in a better position compared with their current position that relies on tax incentives to attract investment. An initial offer of all incremental revenue from the change to the borderless tax under an international tax administrator would be a good place to begin. Before the economic downturn from the COVID-19 pandemic, developed

${ }^{250}$ See ACTION 1, supra note 98, at 20.

${ }^{251}$ DEVEREUX ET AL., supra note 16, at 22-35 (providing very incomplete estimates of revenue lost to base erosion and profit shifting from the digital economy in the $\$ 10$ billion plus range).

${ }^{252}$ See The Tax Gap, IRS, https://www.irs.gov/newsroom/the-tax-gap [https://perma.cc /FZ5P-TNZ3] (last visited July 10, 2020) (estimating a broad non-compliance measure for 2011, 2012, and 2013 at $\$ 441$ billion); Frank J. Bevvino \& Robert A. Page, The Tax Gap: A Competing Values Model, 167 TAX Notes Fed. 991 (May 11, 2020).

253 See Kimberly A. Clausing, The Effect of Profit Shifting on the Corporate Tax Base in the United States and Beyond (Jun. 17, 2016) (unpublished manuscript), https://ssrn.com/abstract=2685442 [https://perma.cc/HE95-MWAX]; see also DEVEREUX ET AL., supra note 16 , at $22-35$.

${ }^{254}$ Ireland's 12.5 percent corporate tax rate has enabled it to capture international headquarters of companies interested in minimal taxes on their European income from intangibles, including Starbucks and Apple. Corporation Tax, IRELAND ReVENUE, https://www.revenue.ie/en/ companies-and-charities/corporation-tax-for-companies/corporation-tax/index.aspx [https://perma .cc/T5XJ-ANMA] (last visited July 10, 2020); Tom Bergin, Special Report: How Starbucks Avoids UK Taxes, REUTERS (Oct. 15, 2012), https:/www.reuters.com/article/us-britain-starbucks-taxidUSBRE89E0EX20121015 [https://perma.cc/8MXQ-K2NL]; Foo Yun Chee, Apple Spars with EU as $\$ 14$ Billion Irish Tax Dispute Drags On, REUTERS (Sept. 18, 2019 https://www.reuters.com/article/us-eu-apple-stateaid-idUSKBN1W31FE [https://perma.cc/36NKGT3R].

255 Annagabriella Colón, Pillar 2 Could Curb Need for Tax Incentives, OECD Official Says, 101 TAX NoTES INT'L 1724 (Mar. 29, 2021). 
economies generally have been able to maintain and perhaps even expand their own infrastructures, including welfare benefit networks that address the relative poverty in developed countries without significantly increasing tax revenue. While no nation admits it can maintain the best that it ever had without a steady increase in tax revenue, such revenue increases have been difficult to find. Anti-tax sentiment in many places has contributed to the political unwillingness of legislatures to increase rates of tax. Decreased rates to meet international tax competition and political pressure to deliver subsidies through the tax system have been more common. As much as developed economies may hope for additional revenue from successful international agreements to reign in base erosion and profit shifting, those economies have not budgeted for increased revenue from BEPS or any other international project. Thus, the incremental revenue from borderless taxation is uncommitted and could be devoted to international development, elimination of absolute poverty, and improved control of worldwide health threats.

The plan might suffice to persuade those non-affluent nations to cease trading low taxes for international investment and to join the universal tax consortium. The commitment to centralized taxation could make many nations less desperate for revenue than they are today and place them in an improved bargaining position with international investors. Relatively low wages and natural resources would leave many jurisdictions attractive for international investment and those that are not would have greater revenue needs and would get a larger share of the international tax revenue pool. Private, shortterm selfish interests might stop being the primary driver of development, enabling those countries to identify and remedy their most acute needs. Improvement of living conditions worldwide might likewise increase consumption and income that would yield even more tax revenue. Rather than devoting that revenue to bulking up the treasuries of the developed economies, the international consortium should be willing to commit that revenue to international development, thereby enhancing the resources of the less developed and developing world countries and broadening the consumer base into the more distant future. ${ }^{256}$

Other traditionally low tax jurisdictions like tax havens might be more difficult to enlist if they customarily offer low tax rates to enhance international investment servicing business and do not have governmental revenue needs. For those countries, coercion may be essential. Since the borderless system would be independent of income sourcing, those jurisdictions would no longer be able to offer international investors freedom from taxation on their investment assets. Most investors would have a sufficient connection with one or more of the consortium countries to provide a basis upon which to tax their income under the borderless system. Historical tax haven economies would simply lose the benefit of offering low taxes. ${ }^{257}$

\footnotetext{
${ }^{256}$ Nathaniel Hendren and Ben Sprung-Keyser, A Unified Welfare Analysis of Government Policies, 135 Q. J. ECON. 1209 (2020).

257 Some retreat from investment management activity from tax haven jurisdictions following a change in U.S. tax law in 1997 that eased the need for actual management activity in the tax haven to avoid the incidence of the U.S. income tax on foreign investors per I.R.C. $\S 864(\mathrm{~b})$. See generally Henry Ordower, Demystifying Hedge Funds: A Design Primer, 7 U.C. Davis Bus. L. J. 323, 362-63 (2007); Joe Maxwell and Ron Tannenbaum, Hedge Fund Administration: Past, Present and Future, AIMA (Nov. 30, 2020), https://www.aima.org/article/hedge-fund-administration-pastpresent-and-future.html\#: :text=The $\% 20 \mathrm{Ten} \% 20 \mathrm{Commandments} \% 20$ required $\% 20 \mathrm{a}$,taxes $\% 20 \mathrm{on}$ $\% 20$ its $\% 20$ offshore $\% 20$ income.\&text $=$ The $\% 201997 \% 20$ Taxpayer $\% 20$ Relief $\% 20$ Act,as $\% 20 \mathrm{we} \% 2$ 0know\%20it\%20today [https:/perma.cc/5FU8-9LLC].
} 
Since the global tax will increase tax revenue, distribution initially should follow a two-step formula. The first step would hold each country harmless from tax revenue loss so that each country, following the transition, receives a share of tax revenue equal to its revenue from income tax in the preceding year or over a rolling average of years, possibly adjusted for inflation. This step preserves the status quo on revenue. While little doubt exists that every country can claim great need for increased tax revenue to fund an unlimited number of important projects in that country, those revenue needs are relative, not absolute. Hence, the second step would require an evaluation that assesses nutrition, housing, education, healthcare, and infrastructure needs of less developed countries and development of a plan to ameliorate any deficits in all categories worldwide. The UN has projects related to some aspects of need already, including hunger. ${ }^{258}$ The remaining revenue would be devoted to the gradual elimination of those deficits-perhaps addressing life-threatening deficits first followed by improvement of living standards everywhere. Amelioration costs would vary widely since they will remain a function of relative local cost of goods and labor.

The method of distributing the incremental revenue may prove more challenging than determining the amount to distribute to each country. Significant regional variations of need contribute to the determination of the amount but distribution through national or regional governments and agencies requires a national or local commitment to deploy the funds as intended. Local corruption is likely to remain an impediment to the intended development and retard progress toward the elimination of absolute poverty. Direct international control of deployment of funds might be the best solution, but that would require further relinquishment of national sovereignty, which quite possibly can endanger international willingness to engage in the borderless tax project. Such control goes well beyond the economically beneficial strategy of a uniform and borderless tax. It might prove even more difficult to persuade nations to yield control over national revenue deployment than to persuade them to become part of the borderless collection system. International control over resource distribution intrudes further upon national selfdetermination. The global pressure to join a worldwide tax consortium and subscribe to a fair tax and distribution formula might serve to moderate corruption where it becomes clear that corruption is impeding intended distribution to diminish the incidence of local poverty, as local residents begin to imagine fundamental changes in living conditions for them if they organize to prevent corrupt actors from seizing the funds and preventing development.

The borderless system affords an opportunity to deploy a portion of the tax revenue to fund a universal basic income (UBI). One country, several non-governmental agencies and various governmental units have experimented with differing permutations of a UBI. ${ }^{259}$ Some UBIs are means tested while others simply distribute a basic sum to each individual. The means-tested, recovery rebates under the CARES Act and subsequent legislation ${ }^{260}$ in

258 See Sustainable Development Programs, Goal 2: Zero Hunger, UN, https://www.un.org/sustainabledevelopment/hunger/ [https://perma.cc/862X-FWWT] (last visited July 10, 2020), For all 17 development goals, including health, education, clean water, and climate actions, see Sustainable Development Programs, UN, http://www.undp.org/content/undp/en /home/sustainable-development-goals.html [https://perma.cc/H8UN-LL64] (last visited June 23, 2020).

${ }^{259}$ Sigal Samuel, Everywhere Basic Income Has Been Tried, in One Map, Vox (Feb. 19, 2020), https://www.vox.com/future-perfect/2020/2/19/21112570/universal-basic-income-ubi-map [https://perma.cc/5L6V-X493].

${ }^{260}$ See Coronavirus Aid, Relief, and Economic Security Act (the CARES Act), Pub. L. 116-136, 134 Stat. 281 (codified as amended in scattered sections of U.S. Code), Consolidated 
the U.S. are a limited form of UBI. ${ }^{261}$ U.S. Democratic presidential primary candidate Andrew Yang included a UBI in his platform. ${ }^{262}$ Some commentators have recommended a universal basic income within national borders to eliminate poverty and distribute welfare while respecting the dignity and autonomy of the individual. ${ }^{263}$ Some opponents of a UBI worry that free money will disincentivize work but some argue that the very limited evidence from existing experiments with UBI does not support that conclusion. ${ }^{264}$

Insofar as the uniform global tax requires taxpayers to report directly to the international taxing agency without the intermediation of any national government, the agency has the direct contact necessary to distribute funds to individuals. If the borderless tax system includes everyone, without regard to income, in its database, it would be a relatively simple matter for the agency to distribute funds directly to those whose incomes fall below a geographically determined minimum amount. Such a system might be less intrusive on national sovereignty than other types of control over funds, as the distributions would be independent of national borders and tied only to the local cost of living and having little to do with any characteristic that might be specific to any country. It is likely, for example, that in many instances, especially those that may be historically arbitrary, two individuals living a short distance apart on opposite sides of a border will have more similar costs of living than two individuals living at a great distance from one another in the same country. ${ }^{265}$ The UBI could supplement direct distribution to national governments yet remain substantially free from the risk of loss through governmental corruption.

\section{CONCLUSION}

This Article proposes an international tax agency to administer a uniform borderless income tax under uniform tax rules. It complements an earlier international tax agency proposal that would have apportioned the income tax base, also determined under substantially uniform rules, among nations to give a more meaningful share of the base to less developed producing economies. This proposal expands the basic concept to collect tax revenue centrally and distribute it among nations as it is needed. Needs for developed economies would include the maintenance of their existing infrastructures including welfare, while needs for less developed economies would include basic needs of the populace - food, shelter, clothing, healthcare, and education. The proposal is aspirational,

Appropriations Act, 2021, Pub. L. 116-260, 134 Stat. 709 (codified as amended in scattered sections of U.S. Code); American Rescue Plan Act of 2021, Pub. L. 117-2, 135 Stat. 4 (codified as amended in scattered sections of U.S. Code).

261 The payments of $\$ 1200$ per individual plus $\$ 500$ per qualifying child were uniform to all residents with income of $\$ 75,000$ or less in either of the two preceding tax years. See section 2201 of the CARES Act adding I.R.C. § 6428.

${ }^{262}$ Matt Stevens and Isabella Grullón Paz, Andrew Yang's \$1,000-a-Month Idea May Have Seemed Absurd Before. Not Now, N.Y. Times (Mar. 18, 2020), https://www.nytimes.com/2020/03/18 /us/politics/universal-basic-income-andrew-yang.html [https://perma.cc/RB5T-RF4T].

263 See Ari Glogower \& Clint Wallace, Shades of Basic Income (Ohio State Pub. L., Working Paper No. 443, 2017), https://ssrn.com/abstract=3122146 [https://perma.cc/3WNW9ZQZ]; Usman Chohan, Universal Basic Income: A Review (Aug. 2017) (unpublished discussion paper) (on file with University of New South Wales), https://papers.ssrn.com/sol3/papers.cfm ?abstract_id=3013634 [https://perma.cc/AH4S-3M6D]; Isabel Ortiz, et al., Basic Income Proposals in Light of ILO Standards: Key Issues and Global Costing (Extension of Social Security, Working Paper No. 62, 2018), https://ssrn.com/abstract=3208737 [https://perma.cc/M6YU-5FBC].

${ }^{264}$ See Donna Lu, Universal Basic Income Seems to Improve Employment and Well-being, NEwSCIENTIST (May 6, 2020), https://www.newscientist.com/article/2242937-universal-basicincome-seems-to-improve-employment-and-well-being/\#ixzz6qA62SZ6x [https://perma.cc/AM2BSYUX]; Samuel, supra note 259.

${ }^{265} \mathrm{Cf}$. Brassey \& Ordower, supra note 37 , at 112-13. 
of course, but it is designed to induce readers to think more globally about basic needs and ask questions like: what should my serendipitously wealthy nation be willing to renounce so that my poor nation neighbor may provide essential services to its populace? The concept of borderless taxation is utopian as it contemplates distribution of worldwide revenue to provide basic human needs for a comfortable and productive life independently of the happenstance of location of one's birth. 